\title{
Advances in Designing and Developing Vaccines, Drugs, and Therapies to Counter Ebola Virus
}

OPEN ACCESS

Edited by:

Hiroyuki Oshiumi,

Kumamoto University, Japan

Reviewed by:

Oscar Negrete,

Sandia National Laboratories

(SNL), United States

Pei Xu,

Sun Yat-sen University, China

Yohei Kurosaki,

Nagasaki University, Japan

*Correspondence:

Kuldeep Dhama

kdhama@rediffmail.com;

Yashpal Singh Malik

malikyps@gmail.com

Specialty section: This article was submitted to Microbial Immunology,

a section of the journal

Frontiers in Immunology

Received: 01 April 2018 Accepted: 23 July 2018 Published: 10 August 2018

Citation:

Dhama K, Karthik K, Khandia R, Chakraborty S, Munjal A, Latheef SK,

Kumar D, Ramakrishnan MA,

Malik YS, Singh R, Malik SVS,

Singh RK and Chaicumpa W (2018)

Advances in Designing and

Developing Vaccines, Drugs, and

Therapies to Counter Ebola Virus.

Front. Immunol. 9:1803.

doi: 10.3389/fimmu.2018.01803
Kuldeep Dhama ${ }^{1 *}$, Kumaragurubaran Karthik ${ }^{2}$, Rekha Khandia ${ }^{3}$, Sandip Chakraborty ${ }^{4}$, Ashok Munjal ${ }^{3}$, Shyma K. Latheef ${ }^{5}$, Deepak Kumar ${ }^{6}$, Muthannan Andavar Ramakrishnan ${ }^{7}$, Yashpal Singh Malik ${ }^{8 *}$, Rajendra Singh ${ }^{1}$, Satya Veer Singh Malik ${ }^{9}$, Raj Kumar Singh ${ }^{10}$ and Wanpen Chaicumpa ${ }^{11}$

${ }^{1}$ Division of Pathology, ICAR-Indian Veterinary Research Institute, Bareilly, India, ${ }^{2}$ Central University Laboratory, Tamil Nadu Veterinary and Animal Sciences University, Chennai, India, ${ }^{3}$ Department of Biochemistry and Genetics, Barkatullah University, Bhopal, India, ${ }^{4}$ Department of Veterinary Microbiology, College of Veterinary Sciences and Animal Husbandry, Agartala, India, ${ }^{5}$ Immunology Section, ICAR-Indian Veterinary Research Institute, Bareilly, India, ${ }^{6}$ Division of Veterinary Biotechnology, ICAR-Indian Veterinary Research Institute, Bareilly, India, 'Division of Virology, ICAR-Indian Veterinary Research Institute, Nainital, Uttarakhand, India, ${ }^{8}$ Division of Biological Standardization, ICAR-Indian Veterinary Research Institute, Bareilly, India, ${ }^{9}$ Division of Veterinary Public Health, ICAR-Indian Veterinary Research Institute, Bareilly, India, ${ }^{10}$ ICAR-Indian Veterinary Research Institute, Bareilly, Uttar Pradesh, India, ${ }^{11}$ Center of Research Excellence on Therapeutic Proteins and Antibody Engineering, Department of Parasitology, Faculty of Medicine Slriraj Hospital, Mahidol University, Bangkok, Thailand

Ebola virus (EBOV), a member of the family Filoviridae, is responsible for causing Ebola virus disease (EVD) (formerly named Ebola hemorrhagic fever). This is a severe, often fatal illness with mortality rates varying from 50 to $90 \%$ in humans. Although the virus and associated disease has been recognized since 1976, it was only when the recent outbreak of EBOV in 2014-2016 highlighted the danger and global impact of this virus, necessitating the need for coming up with the effective vaccines and drugs to counter its pandemic threat. Albeit no commercial vaccine is available so far against EBOV, a few vaccine candidates are under evaluation and clinical trials to assess their prophylactic efficacy. These include recombinant viral vector (recombinant vesicular stomatitis virus vector, chimpanzee adenovirus type 3-vector, and modified vaccinia Ankara virus), Ebola virus-like particles, virus-like replicon particles, DNA, and plant-based vaccines. Due to improvement in the field of genomics and proteomics, epitope-targeted vaccines have gained top priority. Correspondingly, several therapies have also been developed, including immunoglobulins against specific viral structures small cell-penetrating antibody fragments that target intracellular EBOV proteins. Small interfering RNAs and oligomer-mediated inhibition have also been verified for EVD treatment. Other treatment options include viral entry inhibitors, transfusion of convalescent blood/serum, neutralizing antibodies, and gene expression inhibitors. Repurposed drugs, which have proven safety profiles, can be adapted after high-throughput screening for efficacy and potency for EVD treatment. Herbal and other natural products are also being explored for EVD treatment. Further studies to better understand the pathogenesis and antigenic structures of the virus can help in developing an effective vaccine and identifying appropriate antiviral targets. This review presents the recent advances in designing and developing vaccines, drugs, and therapies to counter the EBOV threat.

Keywords: Ebola virus, Ebola virus disease, vaccines, prophylactics, drugs, therapeutics, treatment 


\section{INTRODUCTION}

Ebola virus (EBOV; Zaire ebolavirus) is the causative agent of a severe hemorrhagic fever disease, Ebola virus disease (EVD; formerly called Ebola hemorrhagic fever). It was first recognized in 1976 in northern Democratic Republic of Congo, at that time Zaire (1-3). Since then, EVD is endemic in Africa. Fruit bats are the best-known reservoirs of EBOV (4). EVD is a well-established zoonotic disease; the initial cases of the EVD outbreaks occur after contact with reservoir or materials contaminated with the virus and followed by human-to-human transmission (5). EBOV is not only a serious public health issue but now also designated as category A pathogen and considered as a potential bioterrorism agent $(6,7)$. EBOV causes high mortality rates of up to $88 \%$ in the infected humans (8); therefore, it is classified as a risk group 4 agent and handled under biosafety level- 4 containment. The risk of mortality is relatively greater in the elderly and/or patients with high viral load and poor immune response at the initial stage of the infection (9).

The EBOV belongs to the Filoviridae family and has a unique thin filamentous structure that is $80-\mathrm{nm}$ wide and up to $14-\mu \mathrm{m}$ long. Its envelope is decorated with spikes of trimeric glycoprotein $(G P 1,2)$ which are responsible for mediating viral entry into target cells (function of GP1) (10) and release of viral ribonucleoprotein from endosome to cytoplasm for replication (function of GP2) $(11,12)$. EBOV infects primarily humans, simians, and bats; but other species such as mice, shrew, and duikers may also contact infection $(3,13)$. Of the five identified EBOV species, four species, viz., EBOV, Sudan virus (SUDV; Sudan ebolavirus), Tai Forest virus (TAFV; Tai Forest ebolavirus, formerly Côte d'Ivoire ebolavirus), and Bundibugyo virus (BDBV; Bundibugyo ebolavirus), are known to infect humans and cause disease, whereas Reston virus (RESTV; Reston ebolavirus) is non-human primate (NHP) pathogen.

After an initial incubation period of 3-21 days, the disease progresses quickly to fever, intense fatigue, diarrhea, anorexia, abdominal pain, hiccups, myalgia, vomiting, confusion, and conjunctivitis (14) which may lead to the loss of vision (15). EBOV can spread from males to females through semen (16) and from mother to fetus and infant during gestation and lactation, respectively (17). Of the note, in an EBOV-infected patient, higher concentration of Ebola viral RNA in semen was noticed during the recovery period than the viral concentration in the blood during peak time of infection, suggesting male genital organ as virus predilection site for replication (18). Usually the human immune system mounts a response against infectious pathogens by sensing the pathogen-associated molecular patterns via a variety of pathogen-recognition receptors. Nevertheless, in the case of EBOV, innate immunity is impaired by the immunosuppressive viral proteins including VP35 and VP24, and lymphocytes are depleted as a result of apoptosis caused by inappropriate dendritic cell (DC)-T-cell interaction $(7,19)$. A thorough understanding on the pathogenesis of this deadly virus is essential because of its severe health impacts (20).

The increased incidences and fast spread of EBOV paving into a pandemic flight has compelled more focus of research to develop strategies and remedial measures for mitigating the impact and consequential severity of the viral infection. Even before delineating the less studied Ebola viral genome fully, researchers throughout the globe and health industry were pressured to focus on the development of effective and safe Ebola vaccines and therapeutics $(21,22)$. As of now, no licensed vaccines and direct-acting anti-EBOV agents are available to protect against the lethal viral infection or to treat the disease. To minimize the suffering, EBOV-infected patients are only provided with symptomatic treatment and supportive care. Because of its high pathogenicity and mortality rate, preventive measures, prophylactics, and therapeutics are essential, and researchers worldwide are working to develop effective vaccines, drug, and therapeutics, including passive immunization and antibody-based treatments for EVD (23-26). Prior to the 2014-2016 EBOV outbreak in West Africa, which has been the deadliest EBOV outbreak to date, convalescent blood products from survivors of EVD represented the only recommended treatment option for newly infected persons. Administration of monoclonal antibody (mAb) cocktails (ZMapp, ZMAb, and MB-003) as post-exposure prophylactics have been found to reverse the advanced EVD in NHPs and/or effectively prevented morbidity and mortality in NHPs (27-30).

There is the need for an effective vaccine against EBOV, especially in high-risk areas, to prevent infections in physicians, nurses, and other health-care workers who come into contact with diseased patients (31). Regular monitoring and surveillance of EBOV is essential to control this disease. In the EBOV outbreak, novel surveillance approaches include contact tracing with coordination at the national level and "lockdown" periods, during which household door-to-door reviews are conducted to limit the spread of the virus. Swift identification and confirmation of the Ebola cases and immediate follow-up of appropriate prevention and control measures, including safe burial of dead persons, are crucial practices to counter EBOV (32).

After the onset of EVD, treatment is required, whereas, when EBOV is circulating in population dense areas before infection, prophylactic measures like vaccination are necessary. One of the main challenges in containing EBOV is its presence in remote areas that lack technology and equipment to limit the virus spread. Because of its lethality, EBOV can only be handled in laboratories with biosecurity level-4 containment; thus, only few laboratories in the world can conduct EBOV research and testing of the counter measures against the authentic virus. Recent efforts by several organizations have focused on identifying effective therapies and developing appropriate vaccination strategies (33). Several drugs and vaccines have been developed against EBOV, and the production of low-cost drugs and vaccines against EBOV is essential for everyone, including those in the high-risk areas of the world, to be protected $(26,34)$. As of the acquisition of better knowledge against the pathogen due to improvement in the field of genomics and proteomics, there has been expansion in the field of vaccine synthesis where epitope-based vaccines are gaining top priority (35-37).

The present review aims to discuss advances in designing and development of EBOV vaccines, drugs, antibody-based treatments, and therapeutics, and their clinical efficacy in limiting EVD, thereby providing protection against the disease and alleviating high public health concerns associated with EBOV. 


\section{ADVANCES IN DEVELOPING VACCINES AGAINST EBOV}

There is a clear need for an effective vaccine to prevent the rapid spread of EVD. An inactivated EBOV vaccine was first produced in 1980. This vaccine was tested for efficacy in guinea pigs (7). Since that time, several vaccines against EBOV have been developed, but no vaccine is licensed and available in the market (7). After the massive 2014-2016 outbreak of EBOV, several researchers have begun working to develop an effective vaccine (38). For an EBOV vaccine candidate, a long-lasting immune response is essential; as EBOV remains in the seminal fluid of EVD survivors as long as 401 days post-infection $(39,40)$. Keeping this window of virus persistence, a vaccine conferring immunity at least for 2 years is recommended by the Wellcome Trust-CIDRAP Ebola Vaccine Team B initiative (41). Vaccines like the chimpanzee adenovirus type 3 (ChAd3)-based non-replicating ChAd3-EBO vaccine, prime-boost recombinant adenovirus type 26 vector (Ad26.ZEBOV) followed by the modified vaccinia Ankara vector (MVA-BN-Filoa) vaccine, adenovirus 5-vectored EBOV vaccine, EBOV DNA vaccine, and recombinant vesicular stomatitis virus (rVSV) vector-based vaccine are undergoing clinical trials to evaluate their efficacy against EVD (38). The RNA-dependent RNA polymerase (L) epitope-based vaccine was designed using immunoinformatics. Various software have been used to analyze immunological parameters, and this epitope vaccine was found to be a good candidate for use against EVD (42). Two conserved peptides of EBOV, 79VPSATKRWGFRSGVPP94 from GP1 and 515LHYWTTQDEGAAIGLA530 from GP2, were identified as targets for the development of an epitope-based vaccine (43). Collection of the sequences of EBOV glycoproteins and examination for determining the proteins with greatest immunogenicity have been performed using in silico methods. The best corresponding $\mathrm{B}$ and $\mathrm{T}$ cell epitopes included peptide regions encompassing residues 186-220 and 154HKEGAFFLY162, respectively. Such predicted epitopes can confer the long-lasting immunity against EBOV with better ability of protection (36).

Ebola virus-GP fused with the Fc fragment of a human IgG1 subunit vaccine administrated with alum, QS-21, or polyinosinicpolycytidylic acid-poly-L-lysine carboxymethylcellulose adjuvant induced strong humoral immunity in guinea pigs (44). Effectiveness of a ring vaccine using $\mathrm{rVSV} \Delta \mathrm{G} / \mathrm{EBOVGP}$ in cases of simulated EBOV disease was studied and even this approach can be employed during an outbreak situation (45). Notably, the neutralizing antibodies play a major role in conferring protection against EBOV infections. Thus, an EBOV vaccine capable of effectively inducing a long-lasting neutralizing antibody response is desirable for developing appropriate prevention strategies in combating the infection. In this line, the mucin-like domain of EBOV envelope glycoprotein GP1 has been identified to be critical in induction of protective humoral immune response $(46,47)$. Filorab 1 vaccine revealed desirable immunogenicity without the side effects. The main advantage of this vaccine is its higher immune response induction in chimpanzees (captive) when given orally and also with a single dose [instead of multiple doses as is required by virus-like particle (VLP) vaccine] (48). Modified mRNA-based vaccine constructs, formulated with lipid nanoparticles (LNPs) to facilitate delivery, are being tested against EBOV challenge in guinea pigs. These mRNAs induced robust immune responses and conferred up to $100 \%$ protection from the infection (49).

It is important to note that compilation of data in relation to immune responses (both induced by vaccines and natural infection) and the records of community members showing IgG seropositivity should be kept systematically. Assimilation of such information will help to handle next outbreaks with more rigidity, thereby helping to check EVD-associated disasters at an early stage (50). Vis-à-vis public health workers should also be vaccinated and mass vaccination programs should be undertaken through standardized and coordinated efforts (51).

The following section describes the various types of vaccines and vaccine platforms which are being explored for the development of a successful EBOV vaccine.

\section{Inactivated Vaccines}

Even though inactivated vaccines suffer with the problem of reversion to virulence due to inadequate viral inactivation, various strategies have been constantly explored in developing safe and potent non-replicating vaccine candidates for combating the EBOV infection (52). Both heat- and formalin-inactivated EBOV have been found protective against EBOV infection in a guinea pig model. Inclusion of inactivated vaccine with EBOV E-178 along with interferon (IFN) and immune plasma saved the life of a scientist working on EBOV (53). The protective efficacy of liposome-encapsulated irradiated EBOV, tested in a mouse model, was $100 \%$. However, these viral particles failed to protect NHPs (54). This suggests that murine model is excellent for evaluating vaccine efficacy, but the level of protection might be different in different species and, hence, it is essential to test vaccines in NHPs before proceeding to clinical trials in humans. Heat-, formalin-, or gamma irradiation-killed EBOV vaccines have been found ineffective against EBOV disease; thus, the novel effective vaccine is essentially required (55).

\section{DNA Vaccines}

In DNA vaccines, plasmids are used to express immunogenic antigens. This is an attractive vaccine approach because of the ease of production and simplicity. In addition, DNA vaccine induces both humoral and cellular immune responses. A threeplasmid DNA vaccine comprising the transmembrane-deleted GP sequences from EBOV species Zaire and SUDV-Gulu as well as nucleoprotein (NP) sequence from EBOV was tested in healthy adults. The vaccine was well tolerated, and both $\mathrm{CD} 4^{+}$ and $\mathrm{CD}^{+} \mathrm{T}$ cell responses were elicited (56). An EBOV GP DNA vaccine designed on a consensus alignment of GPs (from strains obtained during 1976-2014), delivered intramuscularly and then electroporated, elicited a strong $\mathrm{T}$ cell response, and protected $100 \%$ of experimental mice from lethal challenge with EBOV (57). The DNA from three strains of EBOV was used to prime human volunteers and boosted with attenuated adenovirus, which acted as delivery vehicle for EBOV DNA into antigen-presenting cells, induced significant humoral- and cell-mediated immune (CMI) responses (58). Intramuscular inoculation of the DNA vaccine through electroporation with DNA plasmid containing 
codon-optimized GP genes of EBOV elicited high levels of IgG and a strong CMI response (measured by IFN- $\gamma$ ELISpot assay) in cynomolgus macaques (59).

Though the preliminary trials using DNA constructs have provided the acceptable safety profiles, the development of low immune titer for a shorter window necessitates repeated vaccinations to overcome this problem. Thus, the use of a potent vaccination regimen based on DNA vaccine platforms does not appear logical for a large population $(60,61)$.

\section{Virus-Like Particles}

Ebola VLPs (EBOV-VLPs or eVLPs) are generated from the expression of viral transmembrane glycoprotein (GP) and structural matrix protein (VP40) in mammalian cells, which undergo self-assembling and budding from host cells and display morphological similarity to infectious EBOV particles (47). Baculovirusderived eVLPs comprising GP, VP40, and NP of EBOV have been found to induce human myeloid DC maturation, suggesting their immunogenicity. Baculovirus-generated VLPs were able to elicit similar levels of protection as 293T cell-derived VLPs and showed protection against virus challenge in a dose-dependent manner (62). Nano-VLPs, produced by sonication of VLPs and filtering to have a mean diameter of approximately $230 \mathrm{~nm}$, increased their thermostability. Unlike native VLPs where GP protein is denatured in a solution by heating, the nano-VLP maintained the conformational integrity of the GP protein at temperature up to $70^{\circ} \mathrm{C}$ and could confer protection in a mouse model (63). VLP containing only VP40 was sufficient to protect mice from EBOV infection. VLP injection leads to an enhanced number of natural killer $(\mathrm{NK})$ cells, which play a crucial role in innate immune protection against lethal EBOV. NK cell protection is dependent on perforin, but not recombinant viral vector vaccines on IFN-gamma secretion (64).

Ebola virus VP40 and GP have been demonstrated to interact with the host protein, BST2, and are associated with viral infections by trapping the newly assembled enveloped virions at the plasma membrane in the infected cells, ultimately induce NF- $\kappa \mathrm{B}$ activity. The effects of EBOV GP1,2, VP40, and BST2 converge on an intracellular signaling pathway leads to neddylation, resulting in the additive response with respect to the induction of NF- $\kappa B$ activity. Exploring the dynamics of this interaction could provide targets for vaccine developments and therapies that can modulate the inflammatory response during EVD (65).

Quantitation of EBOV antigenic particles using proteomic assays like liquid chromatography high resolution mass spectrometry method can be employed for determining the batch quality of vaccine constructs as well as in optimizing the dosages by assessing the amount of GP1 needed to confer effective protection (47).

It is to be noted that though anti-EBOV antibody can mediate effective protection, VLP-vaccinated murine models were shown to survive the EBOV challenge in the absence of detectable serum anti-EBOV antibodies (66). It could also be revealed that adjuvant signaling may circumvent the necessity for B-cell immunity in conferring protection against EBOV. These studies can be valuable for the future characterization, development, and optimization of effective EBOV vaccine candidates (66).

\section{Virus-Like Replicon Particles (VRPs)}

The VRPs are the alternative to live-attenuated vaccines. The use of VRPs eliminates the risk of reversion to the original pathogenic form of live vaccine strains. To generate VRPs, generally filoviruses or alphaviruses are required. Here, while keeping the genes essential for replication, viral structural genes are deleted from full-length genomic cDNA clones. Viral structural genes are replaced with alternative gene(s) coding for an immunogen. Such replicons are able to replicate and transcribe upon transfection in competent cells. The resulting VRPs are able to infect cells only for one cycle. Because of the lack of structural genes, viral progeny are not formed. Viruses such as Venezuelan equine encephalitis virus (VEEV) can be used for production of EBOV antigen instead of structural proteins for the replicon vector. Thus, such vaccines are also quite safe (67). The gene inserted is typically GP, the main target of neutralizing antibodies. VRPs expressing EBOV VP24, VP30, VP35, and VP40 have been evaluated for their protective efficacy in a mouse model, but these were found not to be as protective as EBOV GP and NP antigens. VEEV replicons containing GPs from both EBOV and SUDV showed promising results in cynomolgus macaques after administration of a single dose. Here, two VRPs were constructed that contained the GP of EBOV or SUDV. The animals intramuscularly injected with both of the VRPs, survived viral challenge without exhibiting any clinical signs. The final results indicated that VRP-EBOV GP was able to confer cross-protection against SUDV, whereas VRP-SUDV GP was unable to provide complete protection against EBOV-Zaire challenge (68).

Recently, Ren et al. (69) constructed an alphavirus Semliki forest virus based recombinant replicon vector DREP for efficient and unchecked ex vivo co-expression of EBOV GP and VP40. Active immunization with recombinant DREP vectors possessing GP and VP40 induced cellular and humoral immune responses in murine model against EBOV antigens. This path breaking approach may provide key insights and strategies for designing further effective vaccines to contain EBOV permanently.

\section{Reverse Genetics System for EBOV Vaccine}

A full-length recombinant EBOV infectious clone was constructed using cDNA. By employing reverse genetics method, viable but replication incompetent virus lacking entire VP30 ORF was constructed. The resultant Ebola $\Delta$ VP30 is biologically contained and replication deficient, until VP30 is provided extraneously. Virus replication in cell culture was allowed by growing the virus in Vero cell line that stably expresses VP30, designated VeroVP30 (70). The safety of Ebola $\Delta$ VP30 has been evaluated in mice and guinea pig model and was able to protect from lethal infection (71). The Ebola $\Delta$ VP30 virus inactivated by using hydrogen peroxide protected NHPs after a single immunization. To avoid any incidence of potential recombination events that might result in regaining the replicative efficiency, the vaccine candidate was inactivated by hydrogen peroxide, that creates nicks and breakages in single- or double-stranded DNA or RNA and the virus is completely inactivated while retaining antigenic determinants unaffected (72). 


\section{Recombinant Viral Vector Vaccines}

Engineered viruses are gaining popularity because of their ability to efficiently induce CMI responses (a major part of adaptive immunity along with humoral response), as the antigen is expressed and processed in the cytoplasm. Replicationcompetent rVSV and chimpanzee adenovirus 3 (ChAd-3/cAd3) are the most efficient platforms for designing new vaccines (73). A recombinant vesiculovirus vector containing EBOV GP region (rVSV $\Delta$ G/EBOVGP) was found to be highly effective after a single injection in NHPs $(74,75)$. The vaccine evaluated in pigs showed no disease development and no viral shedding. This indicated that the vaccine could be utilized for herd immunization and it also suggested the safety of the live-attenuated rVSV $\Delta \mathrm{G}$ / EBOVGP vaccine (76). Recently, this $\mathrm{rVSV} \Delta \mathrm{G} / \mathrm{EBOVGP}$ vaccine was evaluated in a randomized double blinded placebo phase III trial in 1,197 humans. There were no adverse effects or death following vaccination, supporting its use as a vaccine (77). The vaccine protected immunocompromised rhesus macaques that had a high number of $C D 4^{+} \mathrm{T}$ cells (78). The rVSV $\Delta \mathrm{G} / \mathrm{EBOVGP}$ vaccine was also studied for its efficacy as a therapy in rhesus monkeys after exposure to EBOV-Makona. This vaccine showed minimal prophylactic efficacy after exposure (79). Efficacy trials initiated to test the rVSV-vectored EBOV vaccine showed greater efficiency at the time of EVD outbreak, if deployed following the strategy of ring vaccination (80).

Another recombinant vaccine (VSV based), i.e., rVSV-Zaire EBOV has been shown to provide substantial protection. From 10 th day of vaccination with this vaccine, no report of any disease was documented, which proved efficacy and effectiveness of rVSV-vectored vaccine in preventing EVD (81). It is interesting to note that seroconversion has been noticed in recipients of recombinant VSV-EBOV (rVSV-EBOV) vaccine by the end of fourth week (i.e., by 28 days) against the Kikwit strain glycoprotein (82). Another recombinant vaccine viz., rVSV-EBOV vaccine was tested as a candidate vaccine. This particular vaccine is under trial in human (phase II/III). It provides protection against only EBOV and is clinically efficient in the clinical set up of ring vaccination format $(38,83,84)$. EBOV and SUDV glycoproteins have been assimilated into a cAdVax vector (adenovirus-based vaccine). In mice, this vaccine has provided full protection $(85,86)$. During recent outbreak in Democratic Republic of the Congo (DRC), rVSV $\Delta$ G-EBOV-GP is being used for ring vaccination in the affected area. Though the vaccine is yet not approved and still under investigation.

In Russia, clinical trial of a vaccine, GamEvac-Combi, has been performed and has been approved to enter in phase III clinical trial (87). The vaccine GamEvac-Combi contained two heterologous expression systems. One is live-attenuated rVSV and the second is a recombinant replication-defective adenovirus type-5 (Ad5). Both the vectors are expressing the same glycoprotein. The rationale to use a combination of two vectors expressing glycoprotein of EBOV is that widely present preexisting immunity to Ad5 limits the use of Ad5 and also a negative correlation between EBOV glycoprotein-specific immune response and preexisting antibodies to Ad5 has been reported (88). Hence, prime immunization with VSV vectored vaccine and then boosting with AD5 vectored vaccine might contribute in compensating negative impacts of preexisting immune response to Ad5. This heterologous vaccine evoked glycoprotein-specific immune response in 100\% volunteers on day $28 \mathrm{th}$. Also, the vaccine is well tolerated and did not significantly altered the body physiological parameters and vital organs. In Liberia, Sierra Leone, and Guinea; the VSV and ChAd3 vectored vaccine are in focus (89).

Another study in mice models has reported that the adoption of a heterologous prime-boost vaccine strategy can result in a durable EBOV-neutralizing antibody response. The chimpanzee serotype 7 adenovirus vectors expressing EBOV GP (AdC7-GP) was used for priming and a truncated version of EBOV GP1 protein (GP1t) was used for boosting. Vaccination response studies showed that AdC7-GP prime/GP1t boost strategy was more potent in generating a sustained and strong immune response as compared to using an individual vaccine construct (90).

Replication-defective recombinant chimpanzee adenovirus type 3-vectored EBOV vaccine (cAd3-EBO) elicited both cellmediated and humoral immunity in NHPs. A vaccine dose of $2 \times 10^{11}$ particle units was found sufficient to induce protective immunity in the NHPs and to eliminate the effect of prior immunity to cAd3 (91). Recombinant VSV vaccine expressing EBOV GP and A/Hanoi/30408/2005 H5N1 hemagglutinin (VSVDGHA-ZGP) protected mice against challenge with both viruses and also cross-protected against $\mathrm{H} 5 \mathrm{~N} 1$ viruses (92).

The utility of adenovirus-vectored EBOV vaccines is limited with preexisting anti-adenoviral antibodies, which significantly lower the GP-specific humoral and T cell responses (88). Six mutations in the genome of MVA virus restrict its host specificity and make it unable to replicate in mammalian cells. A randomized study of a multivalent MVA vaccine encoding GPs from EBOV, SUDV, Marburg virus (MARV), and TAFV NP (MVA$\mathrm{BN}-$ Filo) conducted in 87 participants resulted in no fever. The quadrivalent vaccine formulation has demonstrated the boosting up of both cellular and humoral immune responses against EBOV to several folds (93). Twenty-eight days after immunization, GP-specific IgG was detected with EBOV-specific T cell responses (94). EBOV GP and TAFV NP expressed in an MVA platform assembles into VLPs. Heterologous NPs enhanced VLP formation and offered GP-specific IgG1/IgG2a ratios comparable to those of MVA-BN-Filo (95).

Recombinant cytomegalovirus expressing EBOV GP was found to evoke protective immunity in rhesus monkeys challenged with EBOV (79). Baculovirus-expressed EBOV-Makona strain GP administered with Matrix-M (saponin adjuvant) showed better immunogenicity. Administration of Matrix $M$-adjuvanted vaccine resulted in increased IgG production and $\mathrm{CD}^{+}$and $\mathrm{CD}^{+} \mathrm{T}$ cell production (96). A human parainfluenza virus type 3-vectored vaccine expressing the GP of EBOV (HPIV3/EboGP) was developed as an aerosolized vaccine, and studies in Rhesus macaques showed $100 \%$ protection against challenge with EBOV (97).

Adenovirus 26 vectored glycoprotein/MVA-BN vaccine has recently passed the phase I trial (94). In the European countries including United Kingdom and United States, for the purpose of clinical trial, administration of ChAd-3 vectored vaccine has been adopted. This vaccine expresses the EBOV GP and is available in monovalent and divalent forms $(91,98)$. 
Ebola vaccine potency trials employing replication defective adenoviral vectors ( $\mathrm{rAd}$ ) encoding EBOV GP have come up with promising results in NHP models. Based on such studies, multiple mutant glycoproteins were developed (such as glycoprotein with deleted transmembrane domain) which offers reduced in vitro cytopathogenicity but possessed reduced vaccine-mediated protection. In contrast to this, a point mutated glycoprotein has been reported to offer minimal cytopathogenicity and appropriate immune protection even with a two logs lower vaccine dose (99).

\section{Plant-Based Vaccines and Antibodies}

Viral antigens, including GP, VP40, and NP, elicit protective immune responses. ZMapp, the cocktail of antibodies being used to treat EBOV, is a biopharmaceutical drug. To note, the component antibodies in ZMapp are manufactured in Nicotiana benthamiana using a rapid antibody manufacturing platform. Gene transfer is mediated by a viral vector, and the expression is transient. $N$. benthamiana-derived antibodies produced stronger antibody-dependent cellular cytotoxicity than the analogous antiEBOV mAbs produced in a mammalian Chinese hamster kidney cell line (100). Phoolcharoen (101) expressed a GP1 chimera with the heavy chain of 6D8 mAb, forming an immune complex that was co-expressed with the light chain of the same $\mathrm{mAb}$ in leaves of tobacco plant. The ammonium sulfate-precipitated purified antibodies, along with poly(I:C) adjuvant, a synthetic analog of double-stranded RNA capable of interacting with toll-like receptor (TLR)-3, was found to elicit strong neutralizing anti-EBOV IgG. In addition, the immune complex along with poly(I:C) adjuvant was capable of stimulating a Th1/Th2 response. The experiment suggested the potential application of plant-produced Ebola immune complexes as vaccine candidates. EBOV VP40 was expressed in tobacco plants, and a mouse immunization study showed results that suggested this approach can be used to produce an EBOV vaccine (102).

The utility of plants as bioreactors for the bulk production of ZMapp could be considered to meet the required demand. The glycosylation pattern of mAbs may alter their efficiency and bioactivity, including their binding with the antigenic epitope. Several glycoforms of EBOV mAb13F6 have been prepared using a magnICON expression system. These glycoforms have humanlike biantennary $\mathrm{N}$-glycans with terminal $\mathrm{N}$-acetylglucosamine, resulting in a structure similar to that of human mAbs. Hence, these are beneficial for humans (103).

Both RNA and DNA viruses have been modified to serve as plant-based vectors for the expression of heterologous proteins. Bean yellow dwarf virus, a single stranded-DNA virus, can replicate inside the nucleus of plant cells using their cellular machinery. A vector containing deletions in the coat-encoding genes and gene for the desired antigen may be inserted to form an expression cassette. The delivery of vectors to plants is Agrobacteriummediated (23). mAbs against EBOV are produced by the process of agroinfiltration. In this context, it is noteworthy that lettuce acts as a very good host for the process of agroinfiltration. In lettuce cells, Agrobacterium tumefaciens has been used for delivering viral vectors (104). Neutralizing and protective mAb6D8 against EBOV has been expressed at a concentration of $0.5 \mathrm{mg} / \mathrm{g}$ of leaf mass. This quantity is similar to that generated in magnICON expression system (105). The plant-derived approach to vaccine development is attractive because of the large amount of transient proteins that can be expressed, with the potential for use during high demand for therapeutics and prophylactics (106). Advances in the field of vector expression like plant transient expression system and associated host cell engineering and manufacturing processes paved way for developing biopharmaceutical proteins and therapeutics in commercial basis. The great potentials of such novel approaches have been exploited for evolving therapeutics to counter emerging pandemics of EBOV and influenza that is evidenced from the production of experimental ZMapp antibodies (107).

An overview of various types of vaccines for countering EVD is presented in Table $\mathbf{1}$ and depicted in Figure $\mathbf{1}$.

\section{ADVANCES IN DEVELOPING DRUGS AND THERAPIES AGAINST EBOV}

Momentous leap has been witnessed toward the designing of efficacious EBOV drugs and therapeutics during the short span of only few years, even though the efficacy of several biologicals and vaccines were evaluated during the recent West African outbreak, it remained elusive to ratify a licensed EBOV disease treatment regimen (123).

Management of suspected or confirmed EVD patients includes quarantine, symptomatic, and supportive treatments, including fluid replacement, electrolyte imbalance correction, treating complicated infections, and preventing shock (124). For mitigation of the huge fluid loss and resultant hypovolemia, oral rehydration solutions should be provided adequately and if required anti-diarrheal and anti-emetic drugs need to be administered (125). Brincidofovir, a drug used to treat dsDNA viruses such as adenovirus, herpesviruses, orthopoxviruses, papillomavirus, and polyomaviruses, was approved for emergency treatment of two patients with EBOV infection; however, the clinical efficacy of the drug is unknown (126). Many drugs are being tested to identify specific antiviral drugs to treat EBOV, and new drug candidates are being developed by researchers worldwide $(26,127,128)$.

Favipiravir (T-705), an antiviral drug found useful in treating influenza, has been studied and found effective against EBOV (129-131). Insertional mutagenesis, a high-throughput method to identify genes responsible for virus replication, can be used to develop drug candidates (132). Molecular docking experiments with EBOV GPs can be used for drug designing and the development of therapeutics $(133,134)$. Novel flexible nucleosides called fleximers were found to be effective against recombinant EBOV in Huh7 cells (135). Ribavirin antiviral can be recommended for the treatment of EBOV, since in mouse and monkey models, treatment with ribavirin delayed the death and increased survival rate (136). However, adverse effects associated with its use may limit ribavirin use (137). Lamivudine, an anti-retroviral drug, has been tested by Liberian doctor on 15 EBOV patients with survival of 13 patients (138). However, study by Cong et al. (139) found no survival benefits in Guinea pig model. Similar results were obtained by Hensley et al. (140), with no significant antiviral 


\begin{tabular}{|c|c|c|c|c|c|c|c|}
\hline $\begin{array}{l}\text { S. } \\
\text { No. }\end{array}$ & $\begin{array}{l}\text { Type of vaccine } \\
\text { platform }\end{array}$ & Vaccine & Adjuvant/mode of delivery & Model & Antigen & Inference & Reference \\
\hline \multirow[t]{2}{*}{1} & \multirow[t]{2}{*}{$\begin{array}{l}\text { Inactivated } \\
\text { vaccine }\end{array}$} & $\begin{array}{l}\text { Rabies virus based on inactivated } \\
\text { vaccine (FILORAB1) }\end{array}$ & Glucopyranosyl lipid A & $\begin{array}{l}\text { Cyanomolgus and } \\
\text { rhesus monkeys }\end{array}$ & GP & $\begin{array}{l}100 \% \text { protection against lethal Ebola virus } \\
\text { (EBOV) challenge, with no to mild clinical } \\
\text { signs of disease }\end{array}$ & Johnson et al. (108) \\
\hline & & Virulent EBOV & $\begin{array}{l}\text { Formalin inactivation/heat } \\
\text { inactivation }\end{array}$ & Guinea pig & $\begin{array}{l}\text { Complete virus as } \\
\text { antigen }\end{array}$ & Reduction in mortality & Lupton et al. (53) \\
\hline 2 & $\begin{array}{l}\text { Attenuated } \\
\text { vaccine }\end{array}$ & $\begin{array}{l}\text { Live replication-competent EBOV and } \\
\text { rabies virus-based bivalent vaccine }\end{array}$ & $\begin{array}{l}\text { Direct inoculation of live-attenuated } \\
\text { vaccine }\end{array}$ & Rhesus macaques & GP & $100 \%$ protection from lethal challenge & Blaney et al. (109) \\
\hline \multirow[t]{5}{*}{3} & \multirow[t]{5}{*}{ DNA vaccine } & $\begin{array}{l}\text { Multiagent filovirus DNA vaccine } \\
\text { containing GP of Zaire, Sudan, and } \\
\text { Marburg virus (MARV) }\end{array}$ & $\begin{array}{l}\text { Electrical stimulation at an } \\
\text { amplitude of } 250 \mathrm{~V} / \mathrm{cm} \text { using } \\
\text { TriGridTM electroporation device }\end{array}$ & BALB/c mice & GP & $100 \%$ protection from lethal challenge & Grant-Klein et al. (110) \\
\hline & & & & & \multicolumn{3}{|l|}{ Mutant GP } \\
\hline & & $\begin{array}{l}\text { Synthetic polyvalent-filovirus DNA } \\
\text { vaccine against Zaire, Sudan, and } \\
\text { MARV }\end{array}$ & $\begin{array}{l}\text { pVAX1 mammalian expression } \\
\text { vectors, injected intradermally with } \\
200 \mu \mathrm{g} \text { DA }\end{array}$ & Guinea pigs & $\begin{array}{l}\text { Codon-optimized } \\
\text { GP }\end{array}$ & $100 \%$ protection from lethal challenge & Shedlock et al. (111) \\
\hline & & DNA vaccine against EBOV & $\begin{array}{l}\text { Intramuscular electroporation } \\
\text { (IM-EP) } 500 \mu \mathrm{g} \text { dose }\end{array}$ & Rhesus macaques & $\begin{array}{l}\text { Codon-optimized } \\
\text { GP }\end{array}$ & $86 \%$ protection & Grant-Klein et al. (59) \\
\hline & & $\begin{array}{l}\text { DNA encoding Zaire and Sudan } \\
\text { glycoproteins }\end{array}$ & $4 \mathrm{mg}$ dose in $1 \mathrm{ml}$ volume & $\begin{array}{l}\text { Human healthy } \\
\text { adults }\end{array}$ & Wild-type GP & $\begin{array}{l}\text { Antibody response to the Ebola Zaire } \\
\text { glycoprotein generated }\end{array}$ & Kibuuka et al. (60) \\
\hline 4 & mRNA vaccine & $\begin{array}{l}\text { mRNA molecule encapsulated in a lipid } \\
\text { nanoparticle (LNP) formulation }\end{array}$ & $0.2 \mathrm{mg} / \mathrm{ml}$ & Guinea pigs & $\begin{array}{l}\text { A human Igк signal } \\
\text { peptide or the wild- } \\
\text { type signal peptide } \\
\text { sequence of GP } \\
\text { attached to GP }\end{array}$ & $\begin{array}{l}\text { Potency of mRNA vaccines is enhanced } \\
\text { by LNP }\end{array}$ & Meyer et al. (49) \\
\hline \multirow[t]{4}{*}{5} & \multirow[t]{4}{*}{$\begin{array}{l}\text { Ebola virus-like } \\
\text { particles (VLPS) }\end{array}$} & $\begin{array}{l}\text { pWRG7077 plasmid vectors encoding } \\
\text { for Ebola VP40 and GP }\end{array}$ & $10 \mu \mathrm{g}$ of eVLPs & Balb/c mice & $\begin{array}{l}\text { GP and matrix } \\
\text { protein (VP40) in } \\
\text { mammalian cells }\end{array}$ & $\begin{array}{l}\text { Dose-dependent protection against } \\
\text { lethal challenge }\end{array}$ & Warfield et al. (112) \\
\hline & & $\begin{array}{l}\text { MARV GP and EBOV VP40 or } \\
\text { vice-versa }\end{array}$ & $\begin{array}{l}\text { Intramuscular vaccination with } \\
100 \mu \mathrm{g} \text { of VLPs }+200 \mu \mathrm{l} \mathrm{RIBI} \\
\text { adjuvant }\end{array}$ & $\begin{array}{l}\text { Strain } 13 \text { guinea } \\
\text { pigs }\end{array}$ & GP and VP40 & $\begin{array}{l}\text { Homologous GP is essential and } \\
\text { sufficient for protection against lethal } \\
\text { challenge with homologous virus }\end{array}$ & Swenson et al. (113) \\
\hline & & $\begin{array}{l}\text { pWRG7077 plasmid vectors encoding } \\
\text { for GP, NP, and VP40 }\end{array}$ & $\begin{array}{l}3 \text { intramuscular injections of } \\
250 \mu \mathrm{g} \text { of eVLPs }+0.5 \mathrm{ml} \text { of RIBI } \\
\text { adjuvant }\end{array}$ & $\begin{array}{l}\text { Cynomolgus } \\
\text { macaques }\end{array}$ & GP, NP, and VP40 & $\begin{array}{l}\text { All animals were protected without } \\
\text { showing signs of clinical illness }\end{array}$ & Warfield et al. (114) \\
\hline & & 293T cells transfected with & VLP containing $10 \mu \mathrm{g}$ GP & C57BL/6 mice & $G P+V P 40$ & $\begin{array}{l}\text { VLP-mediated anti-EBOV immunity in } \\
\text { B cell-deficient mice }\end{array}$ & Cooper et al. (66) \\
\hline \multirow[t]{2}{*}{6} & \multirow[t]{2}{*}{$\begin{array}{l}\text { Vaccinia virus- } \\
\text { based vaccine }\end{array}$} & $\begin{array}{l}\text { Modified vaccinia virus Ankara-Bavarian } \\
\text { Nordic }{ }^{\circledR} \text { (MVA-BN) co-expressing VP40 } \\
\text { and glycoprotein (GP) of EBOV Mayinga } \\
\text { and NP of Taï Forest virus }\end{array}$ & $\begin{array}{l}\text { Intramuscular or intravenous } \\
\text { application of } 10^{8} \mathrm{TCID}_{50} \\
\text { of MVA-BN-EBOV-GP or } \\
\text { MVA-BN-EBOV-VLP }\end{array}$ & CBA/J mice & $G P+V P 40$ & $\begin{array}{l}\text { Production of non-infectious } \\
\text { EBOV-VLPs }\end{array}$ & Schweneker et al. (95) \\
\hline & & $\begin{array}{l}\text { Modified vaccinia Ankara (MVA)-based } \\
\text { vaccine expressing the EBOV-Makona } \\
\text { GP and VP40 }\end{array}$ & $1 \times 10^{8} \mathrm{TCID}_{50}$ & Rhesus macaques & $\mathrm{GP}+\mathrm{VP} 40$ & $\begin{array}{l}100 \% \text { protection with single or prime/ } \\
\text { boost vaccination }\end{array}$ & Domi et al. (115) \\
\hline
\end{tabular}




\begin{tabular}{|c|c|c|c|c|c|c|c|}
\hline $\begin{array}{l}\text { S. } \\
\text { No. }\end{array}$ & $\begin{array}{l}\text { Type of vaccine } \\
\text { platform }\end{array}$ & Vaccine & Adjuvant/mode of delivery & Model & Antigen & Inference & Reference \\
\hline \multirow[t]{2}{*}{7} & \multirow{2}{*}{$\begin{array}{l}\text { Venezuelan } \\
\text { equine } \\
\text { encephalitis virus } \\
\text { (VEEV)-based } \\
\text { vaccine }\end{array}$} & VEEV-like replicon particles (VRP) & $10^{7} \mathrm{IU}$ VRP & $\begin{array}{l}\text { Strain } 2 \text { or strain } 13 \\
\text { guinea pigs }\end{array}$ & NP or GP & $\begin{array}{l}\text { NP-VRP and GP-VRP immunized } \\
\text { animals completely protected against } \\
\text { lethal challenge }\end{array}$ & Pushko et al. (116) \\
\hline & & VRP expressing SUDV GP + EBOV GP & $10^{10}$ focus-forming units & $\begin{array}{l}\text { Cynomolgus } \\
\text { macaques }\end{array}$ & GP (EBOV + SUDV) & $\begin{array}{l}100 \% \text { protection against intramuscular } \\
\text { challenge with either SUDV or EBOV }\end{array}$ & Herbert et al. (68) \\
\hline 8 & $\begin{array}{l}\text { Cytomegalovirus } \\
\text { (CMV)-based } \\
\text { vaccines }\end{array}$ & $\begin{array}{l}\text { CD8 }{ }^{+} T \text { cell epitope from EBOV NP } \\
\text { (VYQVNNLEEIC) cloned in mouse CMV } \\
\text { vector }\end{array}$ & $5 \times 10^{5}$ plaque forming units & C57BL/6 mice & NP & $\begin{array}{l}\text { High levels of long-lasting (>8 months) } \\
\mathrm{CD} 8^{+} \mathrm{T} \text { cells are produced }\end{array}$ & Tsuda et al. (117) \\
\hline 9 & $\begin{array}{l}\text { Kunjin virus- } \\
\text { based vaccine }\end{array}$ & Kunjin virus VLPs expressing GP & $5 \times 10^{6} \mathrm{VLPs}$ & $\begin{array}{l}\text { Dunkin-Hartley } \\
\text { guinea pigs }\end{array}$ & GP & $\begin{array}{l}\text { More than } 75 \% \text { survival of animals post } \\
\text { challenge }\end{array}$ & Reynard et al. (118) \\
\hline \multirow[t]{2}{*}{10} & \multirow[t]{2}{*}{$\begin{array}{l}\text { Paramyxovirus- } \\
\text { based vaccines }\end{array}$} & $\begin{array}{l}\text { Human parainfluenza virus type } 3 \\
\text { (HPIV3) clone containing GP }\end{array}$ & $10^{7}$ plaque-forming units & Rhesus monkeys & GP & Double immunization protected animals & Bukreyev et al. (119) \\
\hline & & $\begin{array}{l}\text { Newcastle disease virus clone } \\
\text { containing GP }\end{array}$ & $10^{7}$ plaque-forming units & Rhesus monkeys & GP & $\begin{array}{l}\text { NDV/GP is highly attenuated for } \\
\text { replication in the respiratory tract of } \\
\text { immunized animals and developed } \\
\text { GP-specific mucosal IgA antibodies }\end{array}$ & DiNapoli et al. (120) \\
\hline \multirow[t]{3}{*}{11} & \multirow[t]{3}{*}{$\begin{array}{l}\text { Adenovirus- } \\
\text { based vaccines }\end{array}$} & Adenovirus (rAd5) vaccine GP & $2 \times 10^{9}$ virus particle & $\begin{array}{l}\text { Phase I human } \\
\text { study }\end{array}$ & GP & $\begin{array}{l}\text { Antigen specific humoral and cellular } \\
\text { immune responses were generated }\end{array}$ & Ledgerwood et al. (121) \\
\hline & & $\begin{array}{l}\text { Adenovirus (ChAd3) vaccine boosted } \\
\text { with MVA }\end{array}$ & $\begin{array}{l}\text { Priming dose } 2.5 \times 10^{10} \mathrm{PFU} \text { of } \\
\text { ChAd3 and a boosting dose of } \\
1.5 \times 10^{8} \mathrm{PFU} \text { of MVA }\end{array}$ & $\begin{array}{l}\text { Healthy adult } \\
\text { volunteers }\end{array}$ & GP & $\begin{array}{l}\text { Elicited B-cell and T-cell immune } \\
\text { responses }\end{array}$ & Ledgerwood et al. (91) \\
\hline & & $\begin{array}{l}\text { Chimpanzee serotype } 7 \text { adenovirus } \\
\text { vaccine expressing GP (AdC7-GP) }\end{array}$ & $\begin{array}{l}\text { Prime boosting with AdC7-GP } \\
\left(1 \times 10^{10}\right) \text { and boosting with } 20 \mathrm{mg} \\
\text { Drosophila S2 cells expressed } \\
\text { truncated GP }\end{array}$ & BALB/c mice & GP & $\begin{array}{l}\text { Long-lasting high-titer neutralizing } \\
\text { antibodies production in mice and } \\
\text { efficiently prevented luciferase- } \\
\text { containing reporter EBOV-like } \\
\text { particle entry even at } 18 \text { weeks } \\
\text { post-immunization }\end{array}$ & Chen et al. (90) \\
\hline \multirow[t]{2}{*}{12} & \multirow{2}{*}{$\begin{array}{l}\text { Vesicular } \\
\text { stomatitis virus } \\
\text { (VSV)-based } \\
\text { vaccines }\end{array}$} & VSV GP replaced with EBOV GP & $2 \times 10^{7} \mathrm{PFU}$ & $\begin{array}{l}\text { Healthy adult } \\
\text { volunteers }\end{array}$ & GP & $\begin{array}{l}\text { Anti-Ebola immune responses were } \\
\text { documented }\end{array}$ & Regules et al. (82) \\
\hline & & VSV GP replaced with EBOV GP & $3 \times 10^{5} \mathrm{PFU}$ & $\begin{array}{l}\text { Healthy adult } \\
\text { volunteers }\end{array}$ & GP & $\begin{array}{l}\text { Lowered antibody responses observed } \\
\text { with vaccine associated side effects like } \\
\text { vaccine-induced arthritis and dermatitis }\end{array}$ & Agnandji et al. (122) \\
\hline 13 & $\begin{array}{l}\text { Semliki forest } \\
\text { virus based } \\
\text { vaccines }\end{array}$ & $\begin{array}{l}\text { From DNA-launched replicons (DREP)- } \\
\text { eGFP vector, eGFP replaced with GP } \\
\text { and NP to make DREP-GP and DREP- } \\
\text { VP40 vectors, respectively }\end{array}$ & $10 \mu \mathrm{g}$ plasmid DNA & Balb/c mice & $\mathrm{GP}+\mathrm{VP} 40$ & $\begin{array}{l}\text { EBOV filamentous VLPS were observed } \\
\text { in the supernatant of cells resulting from } \\
\text { co-expression of GP and VP40 and } \\
\text { post immunization, specific humoral } \\
\text { accompanied with a mixed Th1/Th2 } \\
\text { cellular immune response was obtained }\end{array}$ & Ren et al. (69) \\
\hline 14 & $\begin{array}{l}\text { Liposome- } \\
\text { encapsulated } \\
\text { vaccine }\end{array}$ & $\begin{array}{l}\text { Liposome-encapsulated irradiated } \\
\text { EBOV-Zaire }\left(6 \times 10^{6} \text { rads of } \gamma \text {-irradiation }\right. \\
\left.\text { from a }{ }^{60} \mathrm{Co} \text { source }\right)\end{array}$ & $\begin{array}{l}\text { Intravenous inoculation of } 1.0 \mathrm{ml} \\
\text { dose containing } 194 \mu \mathrm{g} \text { of } \\
\text { irradiated EBOV Zaire }+100 \mu \mathrm{gg} \\
\text { of lipid A }\end{array}$ & $\begin{array}{l}\text { BALB/c mice } \\
\text { and Cynomolgus } \\
\text { monkeys }\end{array}$ & $\begin{array}{l}\text { All native EBOV } \\
\text { antigens }\end{array}$ & $\begin{array}{l}\text { All mice protected, however the } \\
\text { immunization failed to protect } \\
\text { Cynomolgus monkeys }\end{array}$ & Rao et al. (54) \\
\hline
\end{tabular}




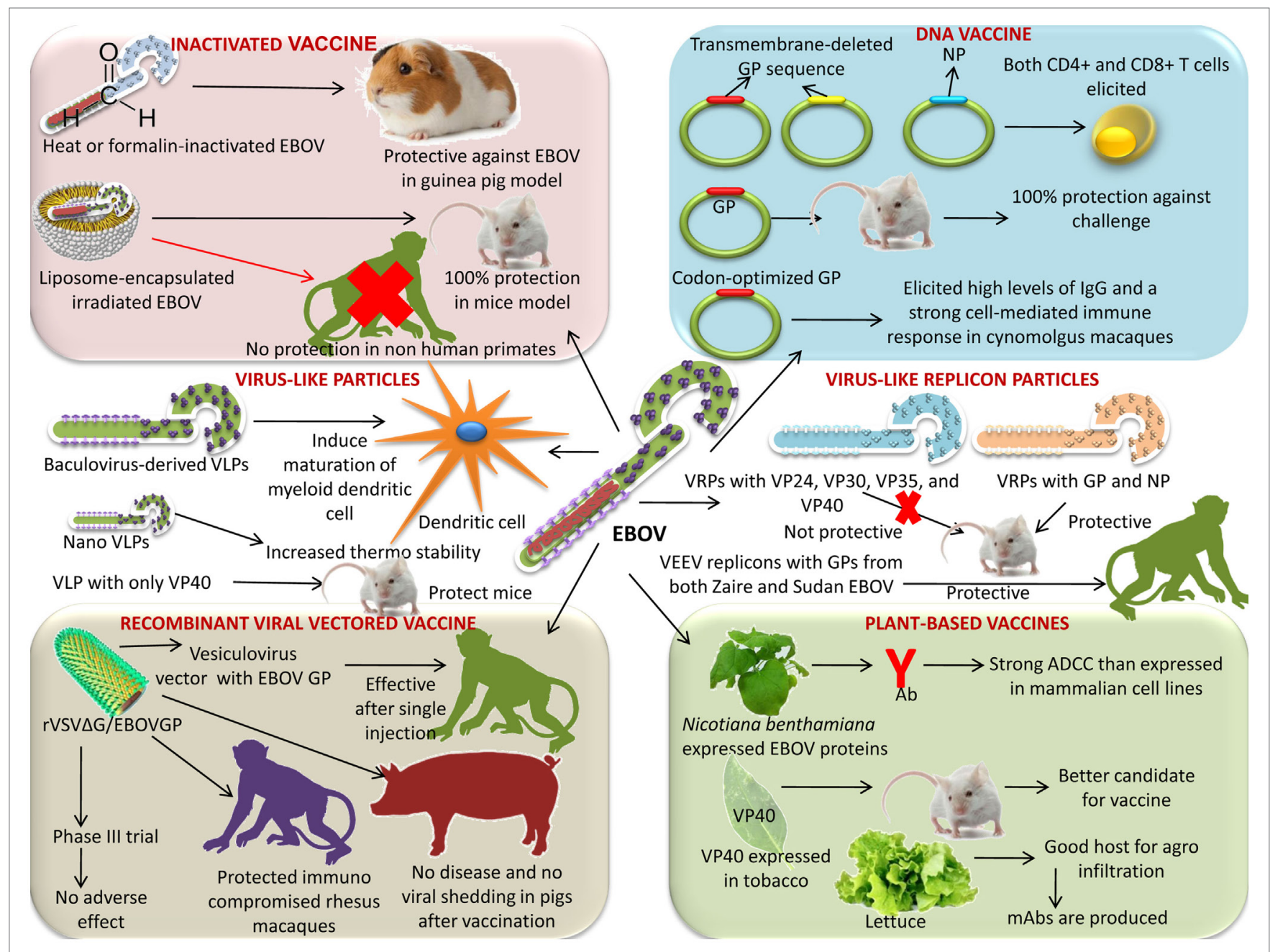

FIGURE 1 | Various vaccine platforms under progress for the development of a successful Ebola virus (EBOV) vaccine. Platforms like inactivated vaccine, DNA vaccine, virus-like particles, virus-like replicon particles (VRPs), plant-based vaccine, and recombinant viral-vectored vaccines are available.

activity of lamivudine against EBOV in Vero E6 cells. Hence, the use of lamivudine may not be advocated.

The docking of VP40, VP35, VP30, and VP24 has been achieved using small molecules belonging to the class of flavonoids and derivatives. Gossypetin and Taxifolin (the two flavonoids of top ranks) showed higher docking scores for every EBOV receptor (141). A virtual analysis of more phytochemicals could help to identify plant-derived products with comparatively higher efficacy and lower toxicity. Adenosine nucleoside analogs such as BCX4430 have been found effective against EBOV in a mouse model. GS-5734, also a nucleoside analog, was found effective against EBOV in a NHP model (142). Using molecular dynamics simulations, graphene sheets are found to associate strongly with VP40 (matrix) protein of EBOV and disrupt VP40 hexamer-hexamer association, crucial to form virus matrix, thereby graphene and similar nanopolymers may be used as therapy or at least disinfectant to reduce the risk of transmission at time of epidemic (143).

The potential of retro-type drugs (molecules that block the retrograde trafficking of bacterial and plant toxins within mammalian cells) must be explored for designing novel therapy against filovirus (144). Retro-2 along with its other two derivatives, Retro- 2.1 and compound 25 could effectively block EBOV and MARV progression in vitro. The derivatives were shown to be more potent inhibitors of filoviral penetration, replication, and progression when compared with their parent compound, as evidenced by pseudo-typed virus assays (144).

\section{EBOV Entry and Inhibitors}

The cell entry of EBOV involves virus binding to the cell surface receptors followed by internalization through macropinocytosis, processing by endosomal proteases, and transport to NiemannPick C1 (NPC1; an internal receptor for EBOV) containing endolysosomes. Phosphatidylinositol-3-phosphate 5-kinase is essential for maturation of endosome, a critical step to the EBOV infection (145). In vitro studies using apilimod, an antagonist of phosphatidylinositol-3-phosphate 5-kinase, showed inhibition of EBOV by blocking the viral particle trafficking to NPC1 containing endolysosomes (146). IFNs are natural antivirals, and type I $(\mathrm{IFN}-\alpha / \beta)$, particularly, is being widely used for the treatment of 
viral diseases. Type I IFN- $\alpha 2 b$ has been evaluated for the treatment of EBOV; however, IFN- $\alpha 2 b$ was not successful, as only delayed death but could not prevent mortality in EBOV-exposed monkeys. IFN- $\gamma$ reduced the mortality rate in mice when administered either before or after EBOV infection (147), suggesting its promise as a prophylactic and/or therapeutic drug for use in EBOV infections. As IFN- $\gamma$ has already been used to treat certain chronic medical conditions and has been approved by the FDA, it can be readily adapted for use against EBOV infections.

Silvestrol extracted from Aglaia foveolata was found to inhibit replication of EBOV and has been suggested as a therapeutic drug to treat acute EBOV infection (148). Supportive treatments like oral rehydration therapy are recommended for children under 5 years of age (149). Web-based identification of therapeutic agents indicated that a single siRNA can inhibit mRNA transcription of three species of EBOV, whereas 75 siRNAs can inhibit at least two species of EBOV. The web server Ebola VCR has been developed, with details available for the development of suitable therapeutic agents (150). Numerous treatment options for EVD are discussed below.

Ebola virus possesses only one surface protein and is responsible for both the receptor binding and fusion of virus-to-host cell endosomal membrane. EBOV glycoprotein binds with lectin receptor DC-SIGN (151). The infection initiated with the binding of EBOV glycoprotein to lectin receptors and internalization of virus majorly through macropinocytosis and as alternative mechanism through clathrin-dependent endocytosis (152). In the low $\mathrm{pH}$ of endosome, cysteine proteases including cathepsin $\mathrm{B}$ and L proteolytically cleave GP. Possibly this proteolytic cleavage exposes the putative receptor-binding region that interacts with NPC1, a receptor facilitating the filovirus entry (153). TIM-1 receptors directly interact with phosphatidylserine on the viral envelope, suggestive of GP independent virus attachment onto the cells. In poorly permissive cells, EBOV infection enhanced by exogenously expressed TIM-1 by 10 - to 30 -folds (154). Other phosphatidylserine interacting proteins like TIM-4 and $\mathrm{Axl}$ (a receptor tyrosine kinase) also have been demonstrated to enhance the infection of several enveloped virus. A benzylpiperazine adamantane diamide-derived compound obtained after screening of a library of small molecules, targets endosomal NPC1, and inhibit infection by VSV particles (VSV) pseudotyped with EBOV GP (155).

Tetrandrin is a potent drug that inhibits the EBOV entry into the cells (156). Two estrogen receptor drugs, clomiphene and toremifene, have been reported to hinder EBOV infection in mice by blocking cell entry and fusion with host cells (157). Amiodarone, an ion channel blocker, has been found to inhibit EBOV entry into cells $(158,159)$. Dendrimers and fullerene $\mathrm{C}_{60}$ have unique symmetrical properties and were recently found effective in inhibiting EBOV entry in vitro (160). Clarithromycin, an antibiotic, inhibits the release of calcium (stimulated by nicotinic acid adenine dinucleotide phosphate) from lysosome and exhibit anti-EBOV activity. Alike clarithromycin, posaconazole, an anti-fungal agent also shows similar anti-EBOV activity. In addition, it also inhibits the functions of NPC1 protein and acid sphingomyelinase activity. Both drugs, i.e., clarithromycin and posaconazole, ultimately inhibit the entry of EBOV into the host cell (161). The drug 5-(N-ethyl- $N$-isopropyl) amiloride inhibits the process of macropinocytosis (a process required for uptake of large filamentous virions, like EBOV) and thus interferes with the viral entry into the cell. Compounds like MLS000394177 and MLS000733230 also inhibit the viral entry into cells (162).

Prunella vulgaris, a Chinese herb, was found to inhibit EBOV entry into cells, using an EBOV-GP-pseudotyped-human immunodeficiency virus (HIV)-1-based vector system (163). Pseudovirions containing EBOV-GP were used for screening of the Prestwick chemical library, which contains 1,200 FDA approved drugs. The assay was based on cell entry of HIV-1-based surrogate in 384-well format. Twenty chemicals were found to inhibit more than $80 \%$ entry and 16 out of them were identified as $\mathrm{G}$ protein-coupled receptor (GPCR) antagonists, which target a range of GPCRs including adrenergic receptors, 5-HT (serotonin) receptors, histamine receptors, muscarinic and acetylcholine receptors. The time-of-addition studies suggested that EBOV entry is stopped at level of initial attachment prior to fusion of virus and cell membrane (164). Quercetin 3- $\beta$-O-D-glucoside (Q3G), a flavonoid derivate, was found to protect mice against EBOV challenge by targeting viral entry (165).

During replication of EBOV, surface GPs undergo proteolytic cleavage in the endosome by several proteases, including cathepsin B (CatB) (166). Thus, proteases may be a good target for the inhibition of EBOV replication. One study showed that, using a synthetic serine protease inhibitor, nafamostat mesilate (NM), caused a reduction in CatB release in rat pancreases. NM was also found to have anti-coagulant properties, which would also be useful in EBOV infections, as EBOV causes disseminated intravascular coagulation. Thus, this drug should be examined in clinical trials to be approved for the treatment of EVD (167). Chemically modified human serum albumin with 3-hydroxyphthalic anhydride (HP-HSA) has been demonstrated with the potential of a therapeutic candidate in resisting the EBOV infection (168).

\section{Transfusion of Convalescent Blood/Serum}

Convalescent serum by definition contains immunoglobulins IgM and IgG but is devoid of red blood cells and clotting factors. Transfusing convalescent whole blood and convalescent plasma from disease survivors has been found to neutralize EBOV and reduce its load; thereafter, the immune response of the patient can provide protection against $\operatorname{EBOV}(169,170)$. The use of whole blood and convalescent serum was approved by the World Health Organization (WHO) during critical EBOV conditions $(171,172)$. Screening of plasma is needed to rule out the presence of residual EBOV RNA and other blood-transmitted pathogens such as HIV, hepatitis B virus, and hepatitis $\mathrm{C}$ virus. Protection is conferred in NHPs through antibody therapy (post-exposure). In humans, this has ultimately paved the way for filovirus therapy by the use of polyclonal/mAb (approved by Food and Drug Administration) (173).

Valuable emergency therapeutics for the treatment of EBOVinfected persons include passive immunization with neutralizing antibodies by the transfer of sera from individuals recovering 
from $\operatorname{EVD}(174,175)$, although it is not considered to render $100 \%$ protection especially after exposure (3 days post-exposure) to EBOV (e.g., Zaire Ebolavirus Makona) (176). Precise immunoglobulins retrieved from equine serum against EBOV were found safe and effective as prophylactic therapy in non-allergic patients (177). Recently developed mAb-based treatments for EVD include mAb114 and MB-003, ZMAb, ZMapp, and MIL77E cocktails (25). ZMAb, consisting of three murine mAbs (1H3, 2G4, and 4G7), administered at a dose of $25 \mathrm{mg} / \mathrm{kg}$ three times, completely protected cynomolgus macaques against EVD. Administration of ZMAb with adenovirus-vectored IFN- $\alpha$ resulted in 75 and $100 \%$ survival of cynomolgus and rhesus macaques, respectively (29). mAbs that bind to the base of GP (4G7 and 2G4) are neutralizing antibodies, whereas mAbs that bind to the glycan cap (mAb114, 1H3, and 13C6) are nonneutralizing antibodies. The chimeric human mAbs 13C6, 6D8, and $13 \mathrm{~F} 6$ possess the variable region from mice and $\mathrm{Fc}$ region of human; mAbs $13 \mathrm{C} 6$ and 6D8 neutralize EBOV in the presence of complement proteins (24). By repeated immunization of mice with glycoproteins of filovirus, generation of pan-EBOV-specific (as well as pan-filovirus) mAbs have been obtained. These panEBOV mAbs have shown reaction with RESTV, SUDV, and other viruses (178).

The components of ZMapp are mAbs (chimeric), viz., c13C6 from MB-003 (already known cocktail of antibody) and c2G4 as well as c4G7 from ZMab (different cocktail of antibody). This drug reversed clinical signs in $100 \%$ of rhesus macaques, even when administered as late as 5 days after EBOV exposure (30). Use of ZMapp, humanized-mouse antibodies, as a therapeutic agent has shown promise in NHPs $(30,84,179)$ and it is a WHOapproved treatment regimen for EVD. Recently, a baby born to an EBOV-infected mother was found positive for EBOV on the first day of life. The baby was treated with ZMapp and the broad spectrum antiviral GS-5734, and, on day 20, the baby was found negative for EBOV (180). MB-003 is another mAb cocktail which is found to be effective in NHPs against variants of EBOV that are resistant to ZMapp (181).

The mechanism of action of mAbs is that they identify the inter-protomer epitope of the GP fusion loop, which is essential for viral membrane fusion, and also neutralize the entry of virus (182). Although several mAbs are available that can neutralize EBOV, there are few mAbs that can neutralize GPs from different EBOV species. In a study by Duehr et al. (183), a panel of eight murine mAbs derived from animals immunized with Zaire ebolavirus was evaluated. The mAbs were tested for binding breadth using a set of recombinant surface GPs from RESTV, TAFV, BDBV, EBOV, SUDV, and MARV. Of the eight, two mAbs (KL-2E5 and KL-2H7) showed binding ability. These two mAbs did not neutralize EBOV; however, they protected mice from infection with a VSV expressing the Zaire ebolavirus GP. Duehr et al. (183) also suggested that Fc-FcR interactions are responsible for the protection of mice in the absence of neutralization. Although ZMapp was found to be effective against Zaire EBOV, it has not shown cross-protection against other species of EBOV. FVM04 (a mAb) has shown cross neutralizing activity against SUDV. So, it can be used to replace one of the components of ZMapp, thereby increasing the range of protection against SUDV, ultimately leading to generation of cross-protective mAbs cocktail (184).

One Fab, KZ52, obtained by panning of phage display library, was derived from the bone marrow of an EVD survivor. Fab KZ52 exhibited 50\% neutralization at a concentration of $8 \mathrm{nM}$ (185). The mAb KZ52 protected guinea pigs from lethal Zaire ebolavirus challenge; however, when an experiment was carried out in rhesus macaques, the antibody failed to protect animals prophylactically and did not inhibit viremia (186). EBOV GP is processed by cathepsins, and the cleaved GP fuses with host cells to form a fusion pore, a passage for the EBOV genome to enter the cytosol for replication. Human mAb KZ52 and monkey mAb JP3K11 bind to conformation-dependent epitopes of GP. KZ52 is directed to bind a conformational non-glycosylated epitope at base of GP and a total 23 residues of GP residues remain in contact with antibody. Out of 23, 15 are contacted through van der Waals interactions and remaining 8 through direct hydrogen bonds (187). At $0.4 \mu \mathrm{g} / \mathrm{ml}$ dose, KZ52 lead to $50 \%$ neutralization. KZ52 protective efficacy is due to inhibition of cathepsin mediated cleavage of GP (23).

Exploring the synergistic effect of different pairs of neutralizing and non-neutralizing anti-EBOV mAbs could provide $100 \%$ protection in mice, revealing the scope of this approach in designing and developing immunotherapeutics and vaccines (188).

Bispecific Trojan-horse antibodies neutralizing other filoviruses have been found to provide protection in mice from multiple EBOV infection (189). Cell-penetrable human scFvs (HuscFvs) (transbodies) that bind to EBOV VP40, a matrix protein pivotal for viral assembly and budding, produced by phage display technology, revealed inhibition of the EBOV-like particles (VLPs) egress from hepatic cells (190). These transbodies were effective in blocking viral assembly and budding within the cells as they bind to several cationic patches in the VP40 C-terminal domain. The transbodies inhibit the function of VP40 by additional mechanisms also; such as binding to N-terminal domain and L-domain peptide WW binding motifs, suggesting the potential of these transbodies as direct acting anti-EBOV agents in future (190). Cell-penetrable HuscFvs specific to a highly conserved interferon-inhibitory domain (IID) of VP35 of EBOV inhibited the VP35 biofunctions in the EBOV replication cycle including polymerase cofactor activity and host IFN-antagonism by forming interface contact with residues of the first basic patch, the central basic patch, end-cap, and residues important for IID multimeric formation for dsRNA binding (191). The cell-penetrable small antibody fragments (HuscFvs) or superantibodies [the term coined by Kohler and Paul (192)] can cross the membrane of all cells but get accumulated intracellularly only where the target antigen is present. Thus, disappearance of the superantibodies from the blood circulation does not imply that they are eliminated from the body. The transbodies to the highly conserved EBOV VP40 and VP35 should be evaluated further using authentic EBOV in animal models of EVD and clinical trials before they can be considered a broadly effective and promising alternative to existing treatment approaches for EVD.

Recently, three mAbs produced in tobacco plants that target the EBOV GP were tested and showed good results in humans (193). Human mAbs against BDBV GP were isolated from patients 
who survived during the 2007 Uganda outbreak. These mAbs were found to have a neutralizing effect against multiple EBOV species, suggesting the possibility of the use of single mAbs as cross-protecting antibodies (194). Another investigation showed that EBOV GPs were conserved across different EBOV species. ELISA revealed that four mAbs namely S3, S12, S17, and S33 were found to show cross-reaction with GPs of five different species of EBOV (195). The discovery of cross-protective antibodies can aid in the development of therapeutic strategies for treatment of EBOV disease (196). In another study, 349 EBOV GP mAbs were isolated from survivors of EVD in an outbreak in Zaire, and 77\% of the mAbs were found to neutralize EBOV (197). Three mAbs of EBOV-GP (Q206, Q314, and Q411) were isolated during the West African EVD outbreak in 2014. Recognition of the novel epitopes has been performed for Q206 and Q411, wherein these mAbs were found protecting mice against EBOV (198). A therapeutic vaccine based on $\mathrm{mAbs}$ has been proposed to sufficiently resolve replication of invasive EBOV, even if administered as a single dose 4 days post-infection (199). Non-neutralizing mAb 5D2 or 7C9 expressing adeno-associated virus (AAV), consistently released $\mathrm{mAb}$ in body and was found $100 \%$ protective against mice adapted EBOV strain. Neutralizing mAb 2G4 conferred $83 \%$ protection and a cocktail of these two mAbs provided $100 \%$ protection when given 7 days prior to infection and sustained protection when immunized animals were challenged 5 months post AAV-mAb immunization (200).

Potential limitations of mAb-based therapies include the requirement for high doses and $\mathrm{mAb}$ mixtures that are outbreakspecific owing to constant viral evolution. Furthermore, epitope mutations could reduce efficacy of the therapeutic mAbs used. Hence, these limiting factors need to be taken care of accordingly with mAbs usages.

\section{EBOV Gene Expression Inhibitors}

Viral gene expression is dependent on host cell machinery and is critical for virus replication. A conserved guanine-rich sequence in the EBOV $\mathrm{L}$ gene has been reported to assemble into quadruplex RNA, targeted by cationic porphyrin TmPyP4 that directs inhibition of the expression of $\mathrm{L}$ gene at the RNA level $(86,201)$. BCX4430 (a nucleoside analog) is a viral RNA polymerase inhibitor, and it has been found effective in protecting mice against lethal challenge of EBOV (202-204). In addition, double-stranded RNA binding protein 76 has been reported to inhibit EBOV polymerase activity (205).

Small molecular inhibitors needed for the synthesis of polyamine have been found to block the expression of EBOV gene. The eukaryotic initiation factor 5A (eIF5A) hypusination and spermidine (a polyamine) are essentially required for the replication of EBOV. However, if eIF5A hypusination is blocked, the gene expression of EBOV is inhibited which subsequently blocks the replication of the virus. Therefore, in-depth understanding of this mechanism at molecular level is essential for developing anti-EBOV drugs (205).

\section{Repurposed Drugs}

It is time taking task to develop a new therapeutic against an infectious agent and till that time new therapy divulged; drug repurposing, i.e., already existing drugs may be screened for their efficacy against pathogen. Owing to the lack of approved EBOV therapies, the screening of potentially efficacious drugs revealed that few of the drugs could be repurposed for EBOV treatment (206) (Table 2). Amiodarone, dronedarone, and verapamil, which are used for tachycardia, arrhythmias, and high blood pressure or angina, respectively, have been screened for their ability to inhibit the entry of filoviruses into cells and found efficacious in in vitro models (158). The use of statins, angiotensin-converting enzyme inhibitors, and angiotensin receptor blockers has also been suggested to attenuate EBOV infection (126). Phosphoinositide 3-kinases inhibitor LY294002 and calcium/calmodulin kinase (CAMK2) inhibitor KN-93 have been reported to reduce EBOV infection in Vero E6 cells. The p38 mitogen-activated protein kinase inhibitor SB202190 was shown to check virus-mediated cytokine storm, as studied in monocyte-derived DC of humans (207). Estrogen re-uptake modulators, viz., toremiphene and clomiphene, although cause in vitro inhibition of the virus entry, but are not free from unwanted side effects like ocular adverse reaction (in case of clomiphene) and serious derangements of electrolytes (in case of toremiphene) at the higher doses. To overcome this, combination therapy is suggested while using such drugs (206). Brincidofovir, a cidofovir analog conjugated with a lipid, can prevent EBOV replication; however, its exact efficacy in an in vivo model needs to be determined (208). Because cyclophilin A (CypA) is not essential for EBOV replication, alisporivir, which inhibits the host protein CypA, has shown limited antiviral effects against EBOV strains (Makona, Mayinga) (209). Emetine, an anti-protozoal agent, and its desmethyl analog cephaeline have potently inhibited EBOV replication and cephaeline is well tolerated in patients than emetine (210).

Rosuvastatin, atorvastatin, and pravastatin have been reported to alleviate inflammation, reduce $\mathrm{C}$-reactive protein and TNF $\alpha$ levels, and impede cholesterol-supported EBOV membrane biosynthesis (232). In EBOV infection, overexpression of the procoagulant tissue factor in monocytes and macrophages and participation of endothelial cells leads to an imbalance in coagulation. The use of recombinant nematode anticoagulant protein c2, an inhibitor of tissue factor-mediated blood coagulation, was found to improve survival of macaques from Ebola hemorrhagic fever, and hence suggested to act as a good treatment module targeting the disease development (228). Anti-malarial drugs such as chloroquine and its structural analogs (hydroxychloroquine, pamaquine, primaquine, and plasmaquine) also act as lysosomotropic agents, preventing endosomal/lysosomal acidification, and thus limiting certain viral infections (233). There are conflicting reports on the therapeutic effects of chloroquine in mouse, hamster, and guinea pig models of EVD. Chloroquine was found to inhibit virus replication in in vitro studies but failed to protect against EBOV infection and disease development in mice, hamsters, and guinea pigs $(234,235)$. Esomeprazole and omeprazole were also found to inhibit viral entry during in vitro studies but higher concentrations of these drugs may be required when to be used in vivo (236). During the EBOV outbreak in Liberia in 2014, a reduction in fever cases was observed following mass administration of malaria chemoprevention drugs (237). 
Because of its competitive anti-heparin potential and interference with viral replication and entry into the cell, the antitrypanosomal agent, Suramin (Germanin or Bayer-205) has been proposed to treat EVD (229). A pyrazine carboxamide derivative namely Favipiravir (an anti-flu medicine), which was used earlier as an inhibitor of influenza virus replication, has been found useful in both therapy and prophylaxis during EBOV epidemic in
West Africa (238-240). Favipiravir and the pyrazine carboxamide derivative T-705 showed positive results in treating patients with medium to high viremias, although these drugs were not found to be effective with very high viremias, but revealed acceptable results during EBOV infection in mouse $(219,221,241)$.

The microtubule inhibitor drugs (vinblastine, vinorelbine/ navelbine, and vincristine), commonly used as anticancer agents,

TABLE 2 | Repurposed drugs used in Ebola virus disease therapy.

\begin{tabular}{|c|c|c|c|c|}
\hline S. No. & Method of screening & Repurposed drug & Function of drug & Reference \\
\hline \multirow[t]{6}{*}{1} & In vitro antiviral activities & Verapamil & Hypertension, angina and arrhythmia & Gehring et al. (158) \\
\hline & & $\begin{array}{l}\text { Teicoplanin (block a late stage of } \\
\text { viral entry) }\end{array}$ & Glycopeptide antibiotic & Wang et al. (211) \\
\hline & & $\begin{array}{l}\text { Nocodazole } \\
\text { Cytochalasin B } \\
\text { Cytochalasin D } \\
\text { Latrunculin A } \\
\text { Jasplakinolide }\end{array}$ & $\begin{array}{l}\text { Cell arrest in G2- or M-phase } \\
\text { A mycotoxin, inhibits network formation by actin filaments } \\
\text { Induces depolymerization of actin filaments } \\
\text { Microtubule inhibitor } \\
\text { Stabilization of filamentous actin }\end{array}$ & Yonezawa et al. (212) \\
\hline & & FGl-104 & Anti-malarial & Kinch et al. (213) \\
\hline & & Amodiaquine & Anti-malarial & Ekins et al. (214) \\
\hline & & $\begin{array}{l}\text { Chloroquine (CQ) } \\
\text { Amiodarone } \\
\text { Prochlorperazine } \\
\text { Benztropine } \\
\text { Azithromycin } \\
\text { Chlortetracycline } \\
\text { Clomiphene }\end{array}$ & $\begin{array}{l}\text { Anti-malarial } \\
\text { Anti-arrhythmic } \\
\text { Dopamine (D2) receptor antagonist; an antipsychotic agent } \\
\text { For treating Parkinson's disease symptoms including } \\
\text { muscle spasms, stiffness, tremors, sweating, drooling, } \\
\text { and poor muscle control } \\
\text { Macrolide antibiotics } \\
\text { Antibiotics } \\
\text { Induce ovaries to produce two or three eggs per cycle }\end{array}$ & $\begin{array}{l}\text { Madrid et al. (215); } \\
\text { Salata et al. (216) }\end{array}$ \\
\hline 2 & $\begin{array}{l}\text { A high-throughput assay for Zaire } \\
\text { Ebola virus (EBOV) has been } \\
\text { developed using the recombinant } \\
\text { EBOV engineered to express the } \\
\text { enhanced green fluorescent protein } \\
\text { (eGFP) (interfere with viral fusion- } \\
\text { worked in in vitro and in vivo) }\end{array}$ & $\begin{array}{l}\text { Clomiphene } \\
\text { Toremifene }\end{array}$ & For treating gynecomastia & Johansen et al. (157) \\
\hline 3 & Mice model (50-90\% survival) & & & Yuan (217) \\
\hline \multirow[t]{2}{*}{4} & In vivo murine EBOV infection model & Bepridil & Calcium channel blocker & Johansen et al. (218) \\
\hline & & $\begin{array}{l}\text { Sertraline (block a late stage of viral } \\
\text { entry) }\end{array}$ & Antidepressant & Johansen et al. (218) \\
\hline 5 & $\begin{array}{l}\text { Recombinant vesicular stomatitis } \\
\text { virus containing Ebola GP protein }\end{array}$ & Tunicamycin & A nucleoside antibiotic & Takada et al. (219) \\
\hline \multirow[t]{2}{*}{6} & $\begin{array}{l}\text { In human-single-arm proof-of- } \\
\text { concept trial in Guinea pigs }\end{array}$ & Favipiravir & Broad-spectrum antiviral activity against RNA viruses & Sissoko et al. (220) \\
\hline & Mouse model (100\% protection) & & & Oestereich et al. (221) \\
\hline 7 & $\begin{array}{l}\text { Vero E6 cells infected with infectious } \\
\text { Mayinga strain of EBOV }\end{array}$ & $\begin{array}{l}\text { Amiodarone } \\
\text { Dronedarone } \\
\text { Verapamil }\end{array}$ & $\begin{array}{l}\text { Anti-arrhythmic therapy and multiple ion channel blocker } \\
\text { Anti-arrhythmic therapy } \\
\mathrm{Ca}^{+2} \text { channel blocker }\end{array}$ & Gehring et al. (158) \\
\hline 8 & Primary human monocyte culture & $\begin{array}{l}\text { 17-allylamino-17- } \\
\text { demethoxygeldanamycin (17-AAG) }\end{array}$ & Inhibitor of heat-shock protein 90 & Smith et al. (222) \\
\hline 9 & $\begin{array}{l}\text { Recombinant EBOV variant Mayinga } \\
\text { expressing enhanced GFP }\end{array}$ & $\begin{array}{l}\text { Retro-2, Retro-2.1, and compound } \\
25\end{array}$ & Inhibit EBOV cell entry & Shtanko et al. (144) \\
\hline 10 & $\begin{array}{l}\text { In } 293 \text { T cells release of Ebola virus- } \\
\text { like particles (VLPs) assay }\end{array}$ & Nilotinib & Treatment for chronic myeloid leukemia in chronic phase & García et al. (223) \\
\hline 11 & $\begin{array}{l}\text { Mouse infection model and Ebola } \\
\text { VLP entry assay }\end{array}$ & Clomiphene & Induce ovaries to produce two or three eggs per cycle & Nelson et al. (224) \\
\hline
\end{tabular}


TABLE 2 | Continued

\begin{tabular}{|c|c|c|c|c|}
\hline S. No. & Method of screening & Repurposed drug & Function of drug & Reference \\
\hline 12 & Ebola VLP entry assay & $\begin{array}{l}\text { Vinblastine } \\
\text { Vinorelbine } \\
\text { Vincristine } \\
\text { Colchicine } \\
\text { Nocodazole } \\
\text { Mebendazole } \\
\text { Albendazole } \\
\text { Tamoxifen } \\
\text { Raloxifene } \\
\text { Clemastine } \\
\text { Maprotiline } \\
\text { Benztropine } \\
\text { Clomipramine } \\
\text { Thiothixene } \\
\text { Trifluoperazine } \\
\text { Dronedarone } \\
\text { Digoxin } \\
\text { Dronedarone } \\
\text { Propafenone } \\
\text { Sunitinib } \\
\text { Daunomycin } \\
\text { Clarithromycin }\end{array}$ & $\begin{array}{l}\text { Microtubule inhibitors } \\
\text { Estrogen receptor modulators } \\
\text { Antihistamine and anticholinergic activities } \\
\text { Antipsychotic/antidepressant } \\
\text { Pump/channel blocker } \\
\text { Anti-arrhythmic drug } \\
\text { Receptor tyrosine kinase (RTK) inhibitor } \\
\text { Cancer treatment } \\
\text { Macrolide antibiotic }\end{array}$ & Kouznetsova et al. (225) \\
\hline 13 & Ebola live virus assays & Posaconazole & Invasive aspergillosis and candidiasis treatment & Sun et al. (161) \\
\hline 14 & $\begin{array}{l}\text { Laboratory animal model C57BL/6 } \\
\text { and BALB/c mice }\end{array}$ & Chloroquine and amodiaquine & Anti-malarial and anti-inflammatory & Madrid et al. (226) \\
\hline 15 & Small molecule chemical screening & NSC 62914 & Scavenger of reactive oxygen species & Panchal et al. (227) \\
\hline 16 & $\begin{array}{l}\text { Rhesus macaque model of Ebola } \\
\text { hemorrhagic fever }\end{array}$ & $\begin{array}{l}\text { Recombinant nematode anti- } \\
\text { coagulant protein c2 }\end{array}$ & $\begin{array}{l}\text { Inhibitor of blood coagulation, attenuates the } \\
\text { proinflammatory response }\end{array}$ & Geisbert et al. (228) \\
\hline 17 & $\begin{array}{l}\text { Vero E6 cells infected with Mayinga } \\
\text { strain of Zaire EBOV }\end{array}$ & Suramin & Trypanosome-caused river blindness treatment & Henß et al. (229) \\
\hline 18 & $\begin{array}{l}\text { Computational analysis using } \\
\text { Surflex, PLANTS, AutoDock, and } \\
\text { AutoDock Vina }\end{array}$ & $\begin{array}{l}\text { Indinavir } \\
\text { Sinefungin } \\
\text { Maraviroc } \\
\text { Abacavir } \\
\text { Telbivudine } \\
\text { Cidofovir }\end{array}$ & $\begin{array}{l}\text { Human immunodeficiency virus protease inhibitor } \\
\text { Anti-fungal } \\
\text { Antiviral drug }\end{array}$ & Zhao et al. (230) \\
\hline 19 & $\begin{array}{l}\text { Computational analysis of novel drug } \\
\text { using CANDOCK (have shown anti- } \\
\text { EBOV potential in other modalities } \\
\text { also) }\end{array}$ & $\begin{array}{l}\text { Raloxifene } \\
\text { Tamoxifen } \\
\text { Clemastine } \\
\text { Deslanoside } \\
\text { Digoxin } \\
\text { Mebendazole } \\
\text { Sertraline } \\
\text { Niclosamide } \\
\text { Sertraline }\end{array}$ & As described above in the table & Chopra et al. (231) \\
\hline
\end{tabular}

have been found effective in inhibiting EBOV VLP entry into HeLa cells even at low concentrations (48-140 nM). Colchicine, a microtubule modulator primarily used for gout, has also been found to show anti-EBOV activity $(225,242)$.

Screening of 1766 FDA approved drugs and 259 experimental drugs revealed that Indinavir, an HIV protease inhibitor, may be effective in reducing the severity of EVD (230). The antiviral drugs including Maraviroc, Abacavir, Telbivudine, and Cidofovir could target the MTase domain of EBOV and inhibit the viral RNAdirected RNA polymerase (230). The Computational Analysis of Novel Drug Opportunities platform was recently developed to screen drugs approved by the FDA. Drugs like enfuvirtide, vancomycin, bleomycin, octreotide, lanreotide, somatostatin, and ubidecarenone (CoQ10) have shown higher activity against EBOV (231). Recently, virtual screening of several thousands of repurposing drugs from Drug Bank has been performed and ibuprofen was selected by realizing its possible inhibitory effect on EBOV infection. The drug has been found to show detectable antiviral effect in cell culture and can thus be used as a very useful molecular template for anti-Ebola viral drug development (243).

\section{Nucleotide Analog Prodrug}

GS-5734 developed by Gilead Sciences falls under this category. Interestingly, clinical trials have been conducted and it has been 
found that the drug is effective in clearing virus from semen $(181,244)$. Administration of GS-5734 in rhesus monkey through intravenous route resulted in suppression of replication of EBOV. It is also important to note that in NHPs, this compound can provide protection post-exposure (245).

\section{Interferons}

Interferons act as potent inhibitors of EBOV as has been proved through in vitro studies conducted involving various types of cells. IFN- $\beta$ - 1 a treatment protected mice against a lethal challenge of EBOV (206). The virus clearance from the blood stream is enhanced by IFN $\beta$-1a leading to resolution of the symptoms of the disease at an early stage (246). Even though there is increased therapeutic usage of IFNs, but certain side effects are also associated with such treatment, viz., fever and myalgia, which must be kept in mind while opting for their use. Moreover, the occurrence of malaria additionally should be ruled out before initiating IFN therapy (206). Tilorone hydrochloride induces IFN response in mice and has been found effective against EBOV due to its action mainly mediated through pathway of innate immunity (IFN related) (247).

\section{Oligomer-Mediated Inhibition}

RNAi and advanced antisense therapies have been reported to provide post-exposure protection against lethal filovirus infections (248). Small interfering (si)RNA targeting RNA polymerase $\mathrm{L}$ protein has shown inhibition of EBOV replication and promising results for its use as a post-exposure therapeutic option (249). siRNAs and phosphorodiamidate morpholino oligomers (PMOs) targeting the EBOV RNA polymerase (L) protein protected NHPs against EVD $(248,249)$. PMOs target co-polymerase protein VP35 and membrane-associated protein VP24 for this protection (250). Antisense PMO-based drugs like AVI 6002, AVI-6003, and LNPs/siRNA (TKM-Ebola) are in clinical trials. TKM-Ebola is a mixture of three siRNAs that target the L, VP24, and VP35 proteins of Zaire EBOV. In NHPs, it efficiently provided postexposure protection $(249,251)$. Although the results were promising, clinicians did not use much TKM-Ebola as it could lead to lethal overproduction of cytokines (a dangerous EBOV-induced inflammatory response) (232). A siRNA LNP product named TKM-130803 has been developed for EVD therapy. Although, the infusion of TKM-130803 at a dosage of $0.3 \mathrm{mg} / \mathrm{kg} /$ day through intravenous route to adult patients with severe clinical signs of EVD was comparable, it did not show an improved protection to the existing and classical controls (252). LNP-encapsulated short siRNAs protected $100 \%$ of rhesus monkeys exhibiting viremia and clinical illness (253). LNP encapsulation is also an effective drug delivery system $(127,253)$.

The inhibitors of hsa-miR-1246, hsa-miR-320a, and hsa-miR196b-5p have been found to decrease EBOV GP cytotoxicity during in vitro studies; hence, miRNA technology can be used to develop useful therapeutics (254). Antiviral drug AVI-7537, targeting the VP24 gene of EBOV, has been shown to be efficacious in mice and monkeys (255). The EBOV-GP (cleaved) molecule acts as a ligand for NPC1, a transmembrane transfer protein. For entry of the virus into the target cell, an interaction between EBOV-GP and NPC1 domain C is necessary. Two small molecules, a sulfonamide (MBX2254) and a triazole thioether (MBX2270), have been identified as novel EBOV inhibitors suppressing EBOV infection in an in vitro model by blocking the entry of virus into target cell via inhibiting GP-NPC1 protein interaction (256). This strategy of targeting viral entry could pave way for the development of an anti-EBOV therapeutic agent.

A brief summary of investigated drugs/biomolecules and therapeutics to treat EBOV infection is presented in Table 3 and depicted in Figure 2.

Of the note, a luciferase reporter system (EBOV-like particle/ EBOVLP) has been developed. It helps in evaluating the in vivo anti-EBOV agents, viz., vaccines and drugs without the necessity of biosafety level-4 facilities. The system appears suitable in studying the process of viral entry also (259). The molecular tweezer CLR01 has been recently reported to inhibit EBOV and Zika virus infection. CLR01 interacts with the lipids in the viral envelop but not with the cellular membrane, thereby it is having very less effect on viability of cells (270). This small molecule has earlier been shown to possess antiviral activity against HIV-1 and herpes viruses. Such broad-spectrum antiviral agents need to be further explored to develop an effective drug against EBOV.

Currently, priority is being given toward investigating various proteins in the host system and viral targets (druggable) (271). Further research works need to be strengthened to identify potent viral or host targets that can be exploited to treat EVD or inhibit EBOV. With advances in bioinformatics tools, it is now possible to identify the active sites of the viral targets which can be utilized as a critical step toward designing and discovering anti-EBOV drugs (272). The involvement of computational tools has widened our approach toward designing drugs (target based) widely. Computational approaches can also countervail the endemic burdens in development of drugs traditionally $(271,273)$. Large libraries can now be effectively screened, ultimately stimulating research activities toward identifying potent antiEBOV drugs. Therapeutic applications of cytokines, recombinant proteins, RNAi technology/RNA interference, TLRs, avian egg yolk antibodies, plant-based pharmaceuticals, nanomedicines, immunomodulatory agents, probiotics, herbs/plant extracts, and others may be explored appropriately to combat EBOV, as these have been found promising against other viral pathogens $(2,249,274-282)$.

\section{CONCLUSION AND FUTURE PERSPECTIVES}

The 2014 EBOV outbreak has been marked as the most widespread lethal viral hemorrhagic attack and prompted a hasty leap in the researches for developing effective vaccines and therapies to counter it. In the case of Ebola, deviations in the touchstone drug/vaccine research approaches may be permitted by authorities to an appropriate extent, considering the devastating and alarming pandemic threat from the disease. In recent years, several therapies have emerged to tackle lethal EBOV infections. A plant-derived formulation of humanized mAbs: "ZMapp" has been used to treat some patients. However, the shortage of ZMapp supply warrants the evaluation and development of new mAbs. 
TABLE 3 | Investigated drugs/biomolecules to treat Ebola virus (EBOV) infection.

\begin{tabular}{|c|c|c|c|c|c|c|c|}
\hline S. No. & $\begin{array}{l}\text { Name of the } \\
\text { therapy }\end{array}$ & $\begin{array}{l}\text { Name of treatment/ } \\
\text { biomolecule }\end{array}$ & $\begin{array}{l}\text { Concentration used } \\
\text { in experiment }\end{array}$ & Platform & $\begin{array}{l}\text { Experimental } \\
\text { model }\end{array}$ & Inference/notes & Reference \\
\hline \multirow[t]{2}{*}{1.} & \multirow{2}{*}{$\begin{array}{l}\text { Convalescent } \\
\text { blood products } \\
\text { therapy }\end{array}$} & Convalescent whole blood & $\begin{array}{l}\text { Transfusion of } \\
150-400 \mathrm{ml} \text { blood }\end{array}$ & - & Human patients & $\begin{array}{l}12.5 \% \text { mortality in treated patients in comparison to } \\
80 \% \text { in untreated patients }\end{array}$ & Mupapa et al. (257) \\
\hline & & Polyclonal lgG & $\begin{array}{l}\text { Intraperitoneal } \\
\text { administration of the } \\
\text { purified anti-EBOV IgG } \\
(100 \mathrm{mg} / \mathrm{kg})\end{array}$ & $\begin{array}{l}\text { Polyclonal lgG } \\
\text { production through } \\
\text { trans-chromosomic } \\
\text { (Tc) bovine platform } \\
\text { technology }\end{array}$ & Mice & $\begin{array}{l}24 \mathrm{~h} \text { post challenge treatment with SAB-139-V2 } \\
\text { antibodies, significant protection was obtained }\end{array}$ & Dye et al. (258) \\
\hline \multirow[t]{7}{*}{2.} & \multirow[t]{7}{*}{$\begin{array}{l}\text { Viral entry } \\
\text { inhibitors }\end{array}$} & MBX2254 and MBX2270 & $\begin{array}{l}\text { MBX2254 }(10 \mu \mathrm{mol} / \mathrm{l}) \\
\text { and MBX2270 } \\
(30 \mu \mathrm{mol} / \mathrm{l}) \text { at }-1,0,2 \text {, } \\
\text { or } 12 \mathrm{~h}\end{array}$ & - & A549 cells & Late stage of EBOV entry is inhibited & Basu et al. (256) \\
\hline & & Tetrandrine & $\mathrm{IC}_{50}=55 \mathrm{nM}$ & - & HeLa cells & $\begin{array}{l}\text { Inhibits infection of human macrophages, the } \\
\text { primary target of EBOV }\end{array}$ & Sakurai et al. (156) \\
\hline & & $\begin{array}{l}\text { MLS000078751 and } \\
\text { MLS000534476, } \\
\text { MLS000394177, } \\
\text { MLS000730532, } \\
\text { MLS000733230 } \\
\text { MLS000555232 } \\
\text { MLS000554255, } \\
\text { MLS001101371 }\end{array}$ & $\begin{array}{l}8 \text { doses ranging from } \\
0.39 \text { up to } 50 \mu \mathrm{M}\end{array}$ & $\begin{array}{l}\text { Quantitative high- } \\
\text { throughput screening } \\
\text { (qHTS) approach } \\
\text { to screen inhibitor } \\
\text { molecules }\end{array}$ & HeLa cells & $\begin{array}{l}\text { Inhibits infection of human macrophages } \\
\text { Inhibits early uptake of virus } \\
\text { Inhibits early endocytic trafficking } \\
\text { Inhibits late endosome trafficking }\end{array}$ & Anantpadma et al. (162) \\
\hline & & $\begin{array}{l}\text { 3-hydroxyphthalic anhydride } \\
\text { (HP)-modified human serum } \\
\text { albumin }\end{array}$ & $\begin{array}{l}\mathrm{EC}_{50} \mathrm{~S} \text { for } 0.068 \text { and } \\
0.124 \text {, respectively, } \\
\text { for Zaire and Sudan } \\
\text { pseudoviruses }\end{array}$ & $\begin{array}{l}\text { Lentivirus-based } \\
\text { pseudotypes }\end{array}$ & Huh-7 cell & $\begin{array}{l}\text { Blocked pseudovirus entry by inhibiting cell surface } \\
\text { attachment }\end{array}$ & Li et al. (168) \\
\hline & & Benztropine mesylate & $\begin{array}{l}\mathrm{IC}_{50} \text { ranging from } 1.7 \\
\text { to } 4.9 \mu \mathrm{M} \text { for different } \\
\text { strains of EBOV }\end{array}$ & $\begin{array}{l}\text { Pseudo-virions platform } \\
\text { for high-throughput } \\
\text { sequencing }\end{array}$ & $\begin{array}{l}\text { A549 and vero } \\
\text { cells }\end{array}$ & $\begin{array}{l}\text { Screening of Prestwick Chemical Library containing } \\
1,200 \text { FDA approved drugs }\end{array}$ & Cheng et al. (164) \\
\hline & & Prunella vulgaris extract & $2.5 \mu \mathrm{g} / \mathrm{ml}$ concentration & $\begin{array}{l}\text { EBOV-GP pseudo- } \\
\text { typed virus (EBOV-GP- } \\
\text { V)-mediated infection } \\
\text { model }\end{array}$ & HEK293T cells & $\begin{array}{l}\text { Enhance anti-EBOV activity of the monoclonal } \\
\text { antibody mAb } 2 \mathrm{G} 4 \text { against EBOV-GP }\end{array}$ & Zhang et al. (163) \\
\hline & & $\begin{array}{l}\text { Quercetin 3- } \beta \text {-O-D-glucoside } \\
\text { (Q3G) }\end{array}$ & $\begin{array}{l}50 \mathrm{mg} / \mathrm{kg} \text { of body } \\
\text { weight }\end{array}$ & VSV-EBOV inhibition & $\begin{array}{l}\text { BALB/c or } \\
\text { C57BL/6 mice } \\
\text { (Charles River) }\end{array}$ & Inhibits glycoprotein-mediated virus entry & Qiu et al. (165) \\
\hline \multirow[t]{2}{*}{3.} & \multirow{2}{*}{$\begin{array}{l}\text { EBOV gene } \\
\text { expression } \\
\text { inhibitors }\end{array}$} & $\begin{array}{l}\text { Double-stranded RNA binding } \\
\text { protein } 76 \text { (DRBP76) }\end{array}$ & $\begin{array}{l}\text { shRNA targeting the } 3^{\prime} \\
\text { UTR of DRBP76 } 6 \text { used }^{\text {a }}\end{array}$ & $\begin{array}{l}\text { Zaire ebolavirus } \\
\text { expressing GFP }\end{array}$ & 293T cells & Inhibits EBOV polymerase activity & Shabman et al. (260) \\
\hline & & Silvestrol & $\mathrm{IC}_{50}=96 \mathrm{nM}$ & $\begin{array}{l}\text { EBOV-infected human } \\
\text { primary macrophages }\end{array}$ & $\begin{array}{l}\text { Huh-7 cells and } \\
\text { primary human } \\
\text { macrophages }\end{array}$ & Strong reduction of VP40 levels & Biedenkopf et al. (148) \\
\hline
\end{tabular}




\begin{tabular}{|c|c|c|c|c|c|c|c|}
\hline S. No. & $\begin{array}{l}\text { Name of the } \\
\text { therapy }\end{array}$ & $\begin{array}{l}\text { Name of treatment/ } \\
\text { biomolecule }\end{array}$ & $\begin{array}{l}\text { Concentration used } \\
\text { in experiment }\end{array}$ & Platform & $\begin{array}{l}\text { Experimental } \\
\text { model }\end{array}$ & Inference/notes & Reference \\
\hline \multirow[t]{3}{*}{4.} & \multirow[t]{3}{*}{ Interferon (IFN) } & IFN- $\alpha$ & $\mathrm{IC}_{50}=0.038 \mu \mathrm{M}$ & \multirow{2}{*}{$\begin{array}{l}\text { In vitro model of Ebola } \\
\text { Zaire replication with } \\
\text { transcription-competent } \\
\text { virus-like particles } \\
\text { (trVLPs) }\end{array}$} & \multirow{2}{*}{ HEK 293T cells } & \multirow[t]{2}{*}{ Inhibits viral replication 24 h post-infection } & \multirow[t]{2}{*}{ McCarthy et al. (261) } \\
\hline & & IFN- $\beta$ & $\mathrm{IC}_{50}=0.016 \mu \mathrm{M}$ & & & & \\
\hline & & IFN $\beta-1 a$ & $30 \mu \mathrm{g} /$ day & Clinical trial & Human patients & $\begin{array}{l}\text { Untreated patients had } \sim 1.5 \text { - to } 1.9 \text {-fold more } \\
\text { likeliness to die than those treated }\end{array}$ & Konde et al. (246) \\
\hline \multirow[t]{9}{*}{5.} & \multirow[t]{9}{*}{$\mathrm{mAb}$} & $\begin{array}{l}\text { ZMAb (combination of } 1 \mathrm{H} 3,2 \mathrm{G} 4 \text {, } \\
\text { and } 4 \mathrm{G} 7 \text { ) }\end{array}$ & $0.1-100 \mu \mathrm{g} / \mathrm{ml}$ & $\begin{array}{l}\text { Pseudo-typed VSV } \\
\text { platform }\end{array}$ & VeroE6 cells & $\begin{array}{l}\text { Antibodies target the GP1-GP2 interface and the } \\
\text { glycan cap }\end{array}$ & Audet et al. (262) \\
\hline & & $\begin{array}{l}\text { ZMapp (cocktail of humanized- } \\
\text { mouse antibodies c2G4 and } \\
\text { c4G7 and c13C6) }\end{array}$ & $\begin{array}{l}\text { Totaling dose of } \\
5 \mathrm{mg} / \text { animal at } 1 \text {-day } \\
\text { post-infection }\end{array}$ & - & $\begin{array}{l}2 \text { patients } \\
\text { evacuated from } \\
\text { Liberia to Atlanta }\end{array}$ & $\begin{array}{l}\text { Showed promise in non-human primates and } \\
\text { clinical improvements in human subjects }\end{array}$ & Qiu et al. (30) \\
\hline & & $\mathrm{KL}-2 \mathrm{E} 5$ and $\mathrm{KL}-2 \mathrm{H} 7$ & $10 \mathrm{mg} / \mathrm{kg}$ & $\begin{array}{l}\text { Pseudo-typed VSV } \\
\text { platform }\end{array}$ & Stat2 $2^{-/-}$mice & $\begin{array}{l}\text { Non-neutralizing but protective action of mAb due } \\
\text { to Fc-FcR interactions }\end{array}$ & Duehr et al. (183) \\
\hline & & FVM04 & $\begin{array}{l}\text { Single intraperitoneal } \\
\text { (IP) injection of } 10 \mathrm{mg} / \\
\mathrm{kg}\end{array}$ & Mouse-adapted EBOV & Mice & $\begin{array}{l}\text { At } 1 \text { dpi post infection single dosing led to full } \\
\text { protection from lethal challenge }\end{array}$ & Howell et al. (184) \\
\hline & & KZ52 & 50 mg/kg & $\begin{array}{l}\text { Guinea pig-adapted } \\
\text { Ebola Zaire virus }\end{array}$ & Guinea pigs & $\begin{array}{l}\text { Dose-dependent protection of guinea pigs } \\
\text { and proven record of efficacy in post-exposure } \\
\text { prophylaxis of EBOV infection }\end{array}$ & Parren et al. (186) \\
\hline & & Q206, Q314, and Q411 & $100 \mu \mathrm{g}$ of each mAb & Mouse-adapted EBOV & BALB/c mice & $\begin{array}{l}\text { Administration of mAbs cocktail at } 1 \text { or } 2 \text { days post } \\
\text { infection, potently neutralized live EBOV }\end{array}$ & Zhang et al. (163) \\
\hline & & $\begin{array}{l}\text { Cell-penetrable human VP40 } \\
\text { binding scFvs (HuscFvs) }\end{array}$ & $40 \mu \mathrm{g} /$ well & $\begin{array}{l}\text { Pseudo-typed lentivirus } \\
\text { particles carrying EBOV } \\
\text { VP40 and GP genes }\end{array}$ & $\begin{array}{l}\text { Huh7 cells } \\
\text { transduced with }\end{array}$ & $\begin{array}{l}\text { Human transbodies effectively inhibit egress of } \\
\text { Ebola virus-like particles from mammalian cells }\end{array}$ & Teimoori et al. (190) \\
\hline & & $\begin{array}{l}\text { Cell-penetrable human scFvs to } \\
\text { IFN-inhibitory domain of VP35 }\end{array}$ & $25 \mu \mathrm{g} /$ well & $\begin{array}{l}\text { EBOV minigenome } \\
\text { and VP35 expression } \\
\text { cassette }\end{array}$ & $\begin{array}{l}\text { HepG2 cells } \\
\text { transduced } \\
\text { with EBOV } \\
\text { minigenome and } \\
\text { VP35 expression } \\
\text { cassette }\end{array}$ & $\begin{array}{l}\text { Human transbodies effectively inhibit VP35 } \\
\text { co-polymerase activity and antagonize VP35- } \\
\text { mediated IFN suppression }\end{array}$ & Seesuay et al. (191) \\
\hline & & $\begin{array}{l}\text { Bispecific antibody (FVM09 548 } \\
\text { and FVM09 MR72 dual-variable } \\
\text { domain immunoglobulin) }\end{array}$ & 20 mg/kg & $\begin{array}{l}\text { Pseudo-typed VSV } \\
\text { platform }\end{array}$ & $\begin{array}{l}\text { Female BALB/c } \\
\text { mice }\end{array}$ & $\begin{array}{l}\text { Specifically and potently neutralize recombinant } \\
\text { VSV-EBOV GP in comparison to the parental mAbs } \\
\text { FVM09, mAb- } 548 \text {, and MR72 which has poor } \\
\text { neutralizing capacity }\end{array}$ & Wec et al. (189) \\
\hline \multirow[t]{3}{*}{6.} & \multirow[t]{3}{*}{$\begin{array}{l}\text { Virus replication } \\
\text { inhibitors }\end{array}$} & $\begin{array}{l}\text { Okadaic acid (toxin produced by } \\
\text { shell fish) }\end{array}$ & $\mathrm{IC}_{50}=130 \mathrm{nM}$ & - & BSR T7/5 cells & $\begin{array}{l}\text { Inhibition of protein phosphatases PP1A and PP2A } \\
\text { by okadaic acid blocks multiplication of EBOV in } \\
\text { target cells }\end{array}$ & Modrof et al. (263) \\
\hline & & $\begin{array}{l}\text { Pyrazinecarboxamide derivative } \\
\text { T-705 (favipiravir) }\end{array}$ & $\begin{array}{l}\text { Treatment (300 mg/ } \\
\text { kg/day) }\end{array}$ & $\begin{array}{l}\text { Used for treating } \\
\text { influenza and other } \\
\text { segmented viruses }\end{array}$ & $\begin{array}{l}\text { In IFNAR }{ }^{-/-} \\
\text {C57BL/6 mice }\end{array}$ & $\begin{array}{l}\text { When treatment initiated } 6 \text { days pre-infection or } \\
\text { post-infection, it prevented mortality of } 100 \% \text { mice } \\
\text { and reduced biochemical correlates of disease }\end{array}$ & Oestereich et al. (221) \\
\hline & & & $\mathrm{IC}_{90}$ of $110 \mu \mathrm{M}$ & & Vero E6 cells & Suppression of EBOV replication by $4 \log _{10}$ units & \\
\hline
\end{tabular}


TABLE 3 | Continued

\begin{tabular}{|c|c|c|c|c|c|c|c|}
\hline S. No. & $\begin{array}{l}\text { Name of the } \\
\text { therapy }\end{array}$ & $\begin{array}{l}\text { Name of treatment/ } \\
\text { biomolecule }\end{array}$ & $\begin{array}{l}\text { Concentration used } \\
\text { in experiment }\end{array}$ & Platform & $\begin{array}{l}\text { Experimental } \\
\text { model }\end{array}$ & Inference/notes & Reference \\
\hline \multirow[t]{3}{*}{7.} & \multirow[t]{3}{*}{$\begin{array}{l}\text { Nucleotide } \\
\text { analog }\end{array}$} & \multirow{2}{*}{$\begin{array}{l}\text { Adenosine nucleoside analog } \\
\text { BCX4430 (interrupt viral RNA } \\
\text { synthesis) }\end{array}$} & $\begin{array}{l}16 \mathrm{mg} / \mathrm{kg} \text { BID dose } \\
\text { group }\end{array}$ & - & $\begin{array}{l}\text { Cynomolgus } \\
\text { macaque }\end{array}$ & Significantly prolonged mean time to death & Taylor et al. (203) \\
\hline & & & $\begin{array}{l}25 \mathrm{mg} / \mathrm{kg} \text { IM BID } \\
\text { (treatment started } \\
30-60 \text { min after } \\
\text { inoculation) }\end{array}$ & - & Rhesus macaque & All animals survived & \\
\hline & & FGl-106 & $3 \mathrm{mg} / \mathrm{kg}$ & $\begin{array}{l}\text { Cell-based assays also } \\
\text { identified inhibitory } \\
\text { activity against } \\
\text { divergent virus families }\end{array}$ & $\begin{array}{l}\text { C57BL/6 or } \\
\text { BALB/c mice }\end{array}$ & $\begin{array}{l}\text { Single dose of FGl-106, administered } 24 \mathrm{~h} \\
\text { post-infection }\end{array}$ & Aman et al. (264) \\
\hline \multirow[t]{2}{*}{8.} & Antivirals & $\begin{array}{l}\text { Genistein and tyrphostin AG1478 } \\
\text { cocktail }\end{array}$ & Up to $100 \mu \mathrm{M}$ & - & HEK 293 cells & $\begin{array}{l}\text { Higher concentrations of genistein and lower } \\
\text { concentrations of tyrphostin AG1478 has higher } \\
\text { inhibition of EBOV }\end{array}$ & Kolokoltsov et al. (265) \\
\hline & & $\begin{array}{l}\text { Carbocyclic 3-deazaadenosine } \\
\text { (S-Adenosylhomocysteine } \\
\text { Hydrolase Inhibitors) }\end{array}$ & $\begin{array}{l}\text { Doses } \geq 0.7 \mathrm{mg} / \mathrm{kg} \\
\text { every } 8 \mathrm{~h}\end{array}$ & - & Adult BALB/c mice & $\begin{array}{l}\text { When treatment initiated at } 0 \text { or day } 1 \text { post } \\
\text { infection, it completely protected animals }\end{array}$ & Huggins et al. (266) \\
\hline \multirow[t]{5}{*}{9.} & $\begin{array}{l}\text { Oligomer- } \\
\text { mediated } \\
\text { inhibition }\end{array}$ & $\begin{array}{l}\text { siRNAs targeting the Zaire } \\
\text { EBOV RNA polymerase } \\
\text { L + VP24 + VP35 in stable } \\
\text { nucleic acid-lipid particles } \\
\text { (SNALPs) }\end{array}$ & $\begin{array}{l}2 \mathrm{mg} / \mathrm{kg} \text { total siRNA } \\
\text { dose }\end{array}$ & - & $\begin{array}{l}\text { Chinese rhesus } \\
\text { macaques }\end{array}$ & $\begin{array}{l}\text { Macaques given seven treatments with SNALPS } \\
\text { were protected after lethal EBOV challenge }\end{array}$ & Geisbert et al. (249) \\
\hline & & $\begin{array}{l}\text { L gene-specific pool of four } \\
\text { siRNAs complexed in SNALPS }\end{array}$ & $\begin{array}{l}\text { A single bolus of } \\
0.75 \mathrm{mg} / \mathrm{kg} \text { siRNA per } \\
\text { kilogram of body weight }\end{array}$ & - & Hartley guinea pigs & $\begin{array}{l}\text { One of the } 4 \text { siRNAs alone is able to completely } \\
\text { protect guinea pigs from a lethal EBOV challenge }\end{array}$ & Geisbert et al. (267) \\
\hline & & $\begin{array}{l}\text { Cell-penetrating peptide } \\
\text { conjugated with } \\
\text { phosphorodiamidate morpholino } \\
\text { oligomers, an uncharged single- } \\
\text { stranded DNA analoge; designed } \\
\text { to base pair with the translation } \\
\text { start site region of VP35 }\end{array}$ & $500 \mu \mathrm{g}$ dose & - & C57BI/6 mice & $\begin{array}{l}\text { Oligomer provided protection to mice when } \\
\text { administered before or after an otherwise lethal } \\
\text { infection }\end{array}$ & Enterlein et al. (268) \\
\hline & & TKM-130803 & $\begin{array}{l}2.24 \times 10^{9} \mathrm{RNA} \text { copies/ } \\
\mathrm{ml} \text { plasma }(0.3 \mathrm{mg} / \mathrm{kg})\end{array}$ & $\begin{array}{l}\text { Single-arm phase II trial, } \\
\text { adults with laboratory- } \\
\text { confirmed Ebola virus } \\
\text { disease (EVD) patients }\end{array}$ & Human patients & $\begin{array}{l}\text { In patients with severe EVD no improvement with } \\
\text { treatment }\end{array}$ & Thi et al. (253) \\
\hline & & miR-607 & - & In silico & - & $\begin{array}{l}\text { Selected mRNA completely blocked all major } 4 \\
\text { EBOVs }\end{array}$ & Golkar et al. (269) \\
\hline
\end{tabular}




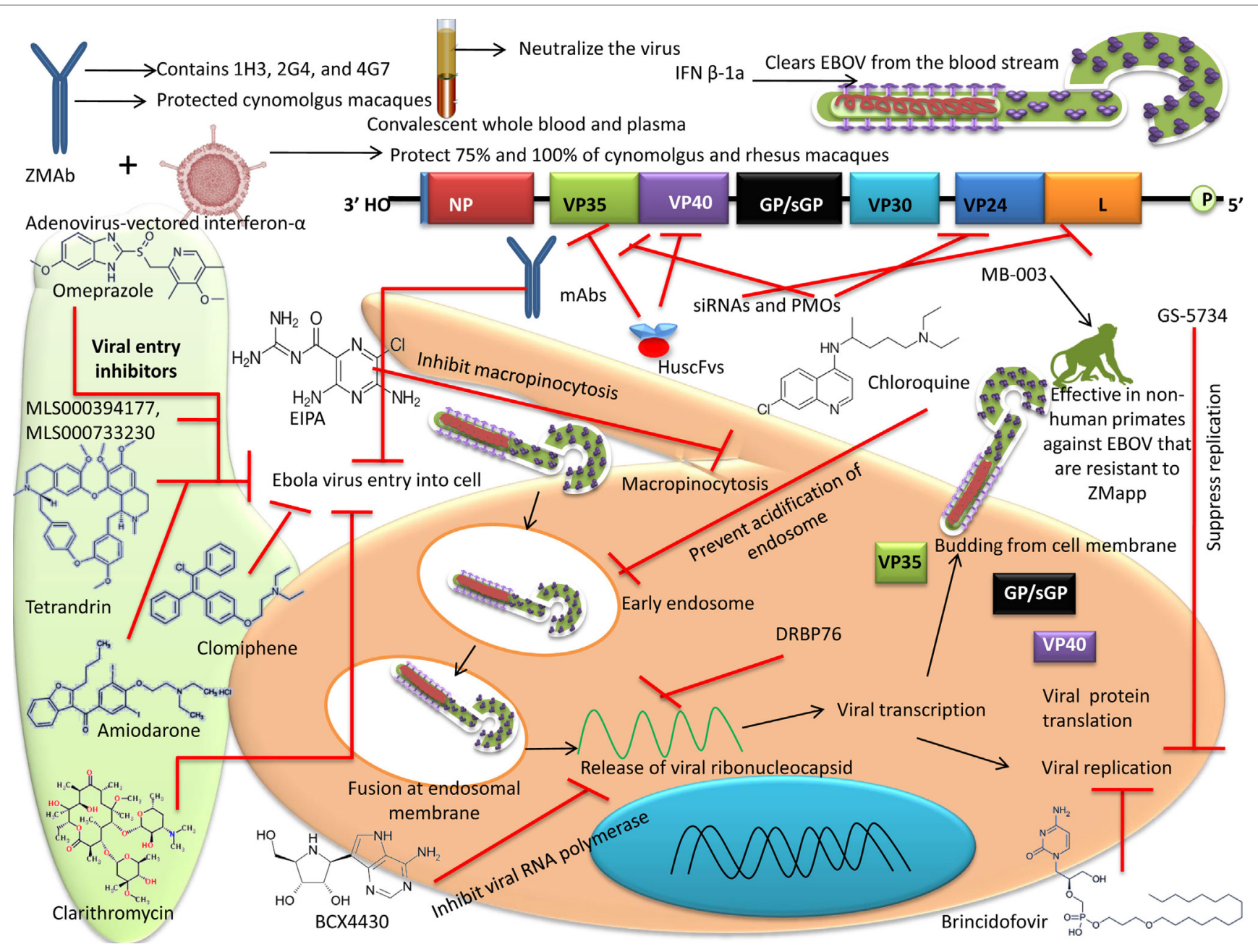

FIGURE 2 | Different therapeutic agents and drugs available for the treatment of Ebola virus disease (EVD). Some agents block the viral entry, some block the RNA polymerase, while some inhibit gene expression. Neutralizing antibodies and mAbs have shown the potential to effectively inhibit Ebola virus (EBOV).

Various drugs have been repurposed to treat potentially lethal disease like EVD. There is a long list of repurposed compounds that have been evaluated as inhibitors of EBOV, including microtubule inhibitors, estrogen receptor and reuptake modulators, kinase inhibitors, histamine antagonists, and ion channel blockers. In-depth studies are still required to understand the pathogenesis and the role of different EBOV peptides, proteins, and antigens and host-virus interactions in EVD. There is also a need to develop economic and effective antivirals and vaccines against EBOV having approach/utility to any part of the world including resource poor countries.

Although the development of vaccines against EBOV began in 1980 , there is still no effective vaccine available to prevent this deadly disease. Hence, the hunt for an effective vaccine is still on. Ebola VLPs play an imperative role in high-throughput screening of anti-EBOV compounds. Because five EBOV species have been reported, a polyvalent vaccine having immunogenic determinants such as GP from each of species would provide broader immunity; indeed, in nonhuman primate experimental studies with a DNA vaccine, this is commonly true. The best first-generation vaccine candidates for EBOV are rVSV and ChAd3, as reflected by their application in providing long duration protection during sporadic outbreaks. Various combinations of antigens from different species of EBOV may be explored to achieve higher protective immune response. The rVSV-based vaccine is being used in Democratic Republic of the Congo. Due to absence of preexisting immunity to VSV, it eliminates several drawbacks and safety concerns associated Ad5-based vaccine. Also, it has show long-term protection in several NHP models, it is an ideal vaccine platform to be used at time of outbreak. Together, the GamEvac-Combi vaccine also seems to be equally promising as it generated immune response in $100 \%$ volunteers.

In addition, mAbs with broad cross-reactivity that will neutralize all five species of EBOV are required to be developed and evaluated for prophylactic and therapeutic uses. Furthermore, effective antibodies may be engineered for homogeneity with human antibodies. Many nucleic acid-based modalities like 
siRNA, miRNA, and PMOs have been tested against EBOV and found functional. In the era of genomics, a computational approach may also be employed to screen large numbers of inhibitory molecules to safeguard human health. Available treatments within the disaster settings; mostly combination of appropriate supportive care and boosting of patient's immune responses, need to be optimized to ensure minimum research/ medical ethics being followed in such settings.

There is always scope for future investigations on the basis of clinical studies that are designed well and statistically supported. Maximum use of supportive therapy (MUST) should be introduced for studying the effects of new therapeutics. The side effects of newer drugs can also be revealed very efficiently by MUST and for this more resources are needed for the Ebola clinics. Though several drugs have been evaluated and vaccines are in development; however, more research is required to develop potent therapeutic and prophylactic agents against EBOV. Apart from these advances, adaptation of appropriate preventive measures and strict biosecurity principles are essential to stop the EBOV outbreaks, limit the spread of virus, and address its public health significance.

\section{REFERENCES}

1. Vogel WH, Viale PH. What you need to know about the Ebola virus. $J A d v$ Pract Oncol (2014) 5(6):471-3.

2. Dhama K, Malik YS, Malik SV, Singh RK. Ebola from emergence to epidemic: the virus and the disease, global preparedness and perspectives. J Infect Dev Ctries (2015) 9:441-55. doi:10.3855/jidc.6197

3. Singh RK, Dhama K, Malik YS, Ramakrishnan MA, Karthik K, Khandia R, et al. Ebola virus - epidemiology, diagnosis, and control: threat to humans, lessons learnt, and preparedness plans - an update on its 40 year's journey. Vet Q (2017) 37(1):98-135. doi:10.1080/01652176.2017.1309474

4. Leroy EM, Epelboin A, Mondonge V, Pourrut X, Gonzalez J-P, MuyembeTamfum J-J, et al. Human Ebola outbreak resulting from direct exposure to fruit bats in Luebo, Democratic Republic of Congo. Vector Borne Zoonotic Dis (2007) 9:6. doi:10.1089/vbz.2008.0167

5. Judson SD, Fischer R, Judson A, Munster VJ. Ecological contexts of index cases and spill over events of different ebolaviruses. PLoS Pathog (2016) 12(8):e1005780. doi:10.1371/journal.ppat.1005780

6. Kosal ME. A new role for public health in bioterrorism deterrence. Front Public Health (2014) 2:278. doi:10.3389/fpubh.2014.00278

7. Wu XX, Yao HP, Wu NP, Gao HN, Wu HB, Jin CZ, et al. Ebolavirus vaccines: progress in the fight against Ebola virus disease. Cell Physiol Biochem (2015) 37(5):1641-58. doi:10.1159/000438531

8. Johnson KM, Lange JV, Webb PA, Murphy FA. Isolation and partial characterisation of a new virus causing acute haemorrhagic fever in Zaire. Lancet (1977) 1(8011):569-71. doi:10.1016/S0140-6736(77)92000-1

9. Skrable K, Roshania R, Mallow M, Wolfman V, Siakor M, Levine AC. The natural history of acute Ebola virus disease among patients managed in five Ebola treatment units in West Africa: a retrospective cohort study. PLoS Negl Trop Dis (2017) 11(7):e0005700. doi:10.1371/journal.pntd.0005700

10. Elliott LH, Kiley MP, McCormick JB. Descriptive analysis of Ebola virus proteins. Virology (1985) 147:169-76. doi:10.1016/0042-6822(85)90236-3

11. Adam B, Lins L, Stroobant V, Thomas A, Brasseur R. Distribution of hydrophobic, residues is crucial for the fusogenic properties of the Ebola virus GP2 fusion peptide. J Virol (2004) 78:2131-6. doi:10.1128/JVI.78.4.21312136.2004

12. Kuhn JH, Andersen KG, Bào Y, Bavari S, Becker S, Bennett RS, et al. Filovirus RefSeq entries: evaluation and selection of filovirus type variants, type sequences, and names. Viruses (2014) 6(9):3663-82. doi:10.3390/v6093663

13. Morvan JM, Deubel V, Gounon P, Nakouné E, Barrière P, Murri S, et al. Identification of Ebola virus sequences present as RNA or DNA in organs of

\section{AUTHOR CONTRIBUTIONS}

All the authors substantially contributed to the conception, design, analysis and interpretation of data, checking and approving final version of the manuscript, and agreed to be accountable for its contents. KD, RK, AM, and KK initiated this review compilation. SC, SL, and RK updated various sections. RKS, YM, DK, and MR reviewed virology and biotechnology aspects. RKS, SM, $\mathrm{RS}$, and WC reviewed recent vaccines and therapies. RK designed tables. KK designed the figures. WC, AM, and $\mathrm{KD}$ overviewed and edited final.

\section{ACKNOWLEDGMENTS}

All the authors acknowledge and thank their respective Institutes and Universities.

\section{FUNDING}

This compilation is a review article written, analyzed and designed by its authors, and required no substantial funding to be stated.

terrestrial small mammals of the Central African Republic. Microbes Infect (1999) 1:1193-201. doi:10.1016/S1286-4579(99)00242-7

14. Rosales-Mendoza S, Nieto-Gómez R, Angulo C. A perspective on the development of plant-made vaccines in the fight against Ebola virus. Front Immunol (2017) 8:252. doi:10.3389/fimmu.2017.00252

15. Varkey JB, Shantha JG, Crozier I, Kraft CS, Lyon GM, Mehta AK, et al. Persistence of Ebola virus in ocular fluid during convalescence. Persistence of Ebola virus in ocular fluid during. N Engl J Med (2015) 372(25):2423-7. doi:10.1056/NEJMoa1500306

16. Uyeki TM, Erickson BR, Brown S, McElroy AK, Cannon D, Gibbons A, et al. Ebola virus persistence in semen of male survivors. Clin Infect Dis (2016) 62(12):1552-5. doi: $10.1093 / \mathrm{cid} / \mathrm{ciw} 202$

17. Black BO, Caluwaerts S, Achar J. Ebola viral disease and pregnancy. Obstet Med (2015) 8(3):108-13. doi:10.1177/1753495X15597354

18. Barnes KG, Kindrachuk J, Lin AE, Wohl S, Qu J, Tostenson SD, et al. Evidence of Ebola virus replication and high concentration in semen of a patient during recovery. Clin Infect Dis (2017) 65(8):1400-3. doi:10.1093/cid/ cix 518

19. Falasca L, Agrati C, Petrosillo N, Di Caro A, Capobianchi MR, Ippolito G, et al. Molecular mechanisms of Ebola virus pathogenesis: focus on cell death. Cell Death Differ (2015) 22:1250-9. doi:10.1038/cdd.2015.67

20. He F, Melén K, Maljanen S, Lundberg R, Jiang M, Österlund P, et al. Ebolavirus protein VP24 interferes with innate immune responses by inhibiting interferon- $\lambda 1$ gene expression. Virology (2017) 509:23-34. doi:10.1016/j. virol.2017.06.002

21. Babalola MO. The strengths, weaknesses, opportunities, and threats (SWOTS) analyses of the Ebola virus - paper retracted. Afr J Infect Dis (2016) 10(2): 69-88. doi:10.21010/ajid.v10i2.2

22. Banadyga L, Wong G, Qiu X. Small animal models for evaluating filovirus countermeasures. ACS Infect Dis (2018). doi:10.1021/acsinfecdis. $7 \mathrm{~b} 00266$

23. Hiatt A, Pauly M, Whaley K, Qiu X, Kobinger G, Zeitlin L. The emergence of antibody therapies for Ebola. Hum Antibodies (2015) 23(3-4):49-56. doi:10.3233/HAB-150284

24. Moekotte AL, Huson MA, van der Ende AJ, Agnandji ST, Huizenga E, Goorhuis A, et al. Monoclonal antibodies for the treatment of Ebola virus disease. Expert Opin Investig Drugs (2016) 25(11):1325-35. doi:10.1080/ 13543784.2016.1240785

25. Mendoza EJ, Racine T, Kobinger GP. The ongoing evolution of antibody-based treatments for Ebola virus infection. Immunotherapy (2017) 9(5):435-50. doi:10.2217/imt-2017-0010 
26. Wu W, Liu S. The drug targets and antiviral molecules for treatment of Ebola virus infection. Curr Top Med Chem (2017) 17(3):361-70. doi:10.2174/ 1568026616666160829161318

27. Marzi A, Yoshida R, Miyamoto H, Ishijima M, Suzuki Y, Higuchi M, et al. Protective efficacy of neutralizing monoclonal antibodies in a nonhuman primate model of Ebola hemorrhagic fever. PLoS One (2012) 7:e36192. doi:10.1371/journal.pone.0036192

28. Olinger GG Jr, Pettitt J, Kim D, Working C, Bohorov O, Bratcher B, et al. Delayed treatment of Ebola virus infection with plant-derived monoclonal antibodies provides protection in rhesus macaques. Proc Natl Acad Sci U S A (2012) 109:18030-5. doi:10.1073/pnas.1213709109

29. Qiu X, Audet J, Wong G, Pillet S, Bello A, Cabral T, et al. Successful treatment of Ebola virus-infected cynomolgus macaques with monoclonal antibodies. Sci Transl Med (2012) 4(138):138ra81. doi:10.1126/scitranslmed.3003876

30. Qiu X, Wong G, Audet J, Bello A, Fernando L, Alimonti JB, et al. Reversion of advanced Ebola virus disease in nonhuman primates with ZMapp. Nature (2014) 514(7520):47-53. doi:10.1038/nature13777

31. Kanapathipillai R, Henao Restrepo AM, Fast P, Wood D, Dye C, Kieny M-P, et al. Ebola vaccine - an urgent international priority. New Engl J Med (2014) 371:2249-51. doi:10.1056/NEJMp1412166

32. Houlihan CF, Youkee D, Brown CS. Novel surveillance methods for the control of Ebola virus disease. Int Health (2017) 9(3):139-41. doi:10.1093/ inthealth/ihx010

33. Joffe S. Evaluating novel therapies during the Ebola epidemic. JAMA (2014) 312:1299-300. doi:10.1001/jama.2014.12867

34. Rios-Huerta R, Monreal-Escalante E, Govea-Alonso DO, Angulo C, RosalesMendoza S. Expression of an immunogenic LTB-based chimeric protein targeting Zaire ebolavirus epitopes from GP1 in plant cells. Plant Cell Rep (2017) 36(2):355-65. doi:10.1007/s00299-016-2088-6

35. Sharmin R, Islam AB. A highly conserved WDYPKCDRA epitope in the RNA directed RNA polymerase of human coronaviruses can be used as epitope-based universal vaccine design. BMC Bioinformatics (2014) 15(161):1471-2105. doi:10.1186/1471-2105-15-161

36. Dash R, Das R, Junaid M, Akash MFC, Islam A, Hosen SMZ. In-silico based vaccine design against Ebola virus glycoprotein. Adv Appl Bioinform Chem (2017) 10:11-28. doi:10.2147/AABC.S115859

37. Gera P, Gupta A, Verma P, Singh J, Gupta J. Recent advances in vaccine development against Ebola threat as bioweapon. Virus disease (2017) 28(3):242-6. doi:10.1007/s13337-017-0398-0

38. Medaglini D, Siegrist CA. Immunomonitoring of human responses to the rVSV-ZEBOV Ebola vaccine. Curr Opin Virol (2017) 23:88-94. doi:10.1016/j. coviro.2017.03.008

39. Mate SE, Kugelman JR, Nyenswah TG, Ladner JT, Wiley MR, CordierLassalle T, et al. Molecular evidence of sexual transmission of Ebola virus. N Engl J Med (2015) 373(25):2448-54. doi:10.1056/NEJMoa1509773

40. Sissoko D, Duraffour S, Kerber R, Kolie JS, Beavogui AH, Camara AM, et al. Persistence and clearance of Ebola virus RNA from seminal fluid of Ebola virus disease survivors: a longitudinal analysis and modelling study. Lancet Glob Health (2017) 5(1):e80-8. doi:10.1016/S2214-109X(16)30243-1

41. Osterholm M, Moore K, Ostrowsky J, Kimball-Baker K, Farrar J, Wellcome Trust CEVTB. The Ebola Vaccine Team B: a model for promoting the rapid development of medical countermeasures for emerging infectious disease threats. Lancet Infect Dis (2016) 16:e1-9. doi:10.1016/S1473-3099(15) 00416-8

42. Oany AR, Sharmin T, Chowdhury AS, Jyoti TP, Hasan MA. Highly conserved regions in Ebola virus RNA dependent RNA polymerase may be act as a universal novel peptide vaccine target: a computational approach. In silico Pharmacol (2015) 3(1):7. doi:10.1186/s40203-015-0011-4

43. Yasmin T, Nabi AH. B and T cell epitope-based peptides predicted from evolutionarily conserved and whole protein sequences of Ebola virus as vaccine targets. Scand J Immunol (2016) 83(5):321-37. doi:10.1111/sji.12425

44. Konduru K, Shurtleff AC, Bradfute SB, Nakamura S, Bavari S, Kaplan G. Ebolavirus glycoprotein FC fusion protein protects guinea pigs against lethal challenge. PLoS One (2016) 11(9):e0162446. doi:10.1371/journal. pone. 0162446

45. Merler S, Ajelli M, Fumanelli L, Parlamento S, Pastore Y, Piontti A, et al. Containing Ebola at the source with ring vaccination. PLoS Negl Trop Dis (2016) 10(11):e0005093. doi:10.1371/journal.pntd.0005093
46. Cook JD, Lee JE. The secret life of viral entry glycoproteins: moonlighting in immune evasion. PLoS Pathog (2013) 9(5):e1003258. doi:10.1371/journal. ppat. 1003258

47. Cazares LH, Ward MD, Brueggemann EE, Kenny T, Demond P, Mahone CR, et al. Development of a liquid chromatography high resolution mass spectrometry method for the quantitation of viral envelope glycoprotein in Ebola virus-like particle vaccine preparations. Clin Proteomics (2016) 13(1):18. doi:10.1186/s12014-016-9119-8

48. Walsh PD, Kurup D, Hasselschwert DL, Wirblich C, Goetzmann JE, Schnell MJ. The final (oral Ebola) vaccine trial on captive Chimpanzees. Sci Rep (2017) 7:43339. doi:10.1038/srep43339

49. Meyer M, Huang E, Yuzhakov O, Ramanathan P, Ciaramella G, Bukreyev A. Modified mRNA-based vaccines elicit robust immune responses and protect guinea pigs from Ebola virus disease. J Infect Dis (2018) 217(3):451-5. doi:10.1093/infdis/jix592

50. Lambe T, Bowyer G, Ewer KJ. A review of phase I trials of Ebola virus vaccines: what can we learn from the race to develop novel vaccines? Phil Trans $R$ Soc B (2016) 372:20160295. doi:10.1098/rstb.2016.0295

51. Walldorf JA, Cloessner EA, Hyde TB, MacNeil A; CDC Emergency Ebola Vaccine Taskforce. Considerations for use of Ebola vaccine during an emergency response. Vaccine (2017). doi:10.1016/j.vaccine.2017.08.058

52. Blaney JE, Wirblich C, Papaneri AB, Johnson RF, Myers CJ, Juelich TL, et al. Inactivated or live-attenuated bivalent vaccines that confer protection against rabies and Ebola viruses. J Virol (2011) 85(20):10605-16. doi:10.1128/ JVI.00558-11

53. Lupton HW, Lambert RD, Bumgardner DL, Moe JB, Eddy GA. Inactivated vaccine for Ebola virus efficacious in guineapig model. Lancet (1980) 2(8207):1294-5. doi:10.1016/S0140-6736(80)92352-1

54. Rao M, Bray M, Alving CR, Jahrling P, Matyas GR. Induction of immune responses in mice and monkeys to Ebola virus after immunization with liposome-encapsulated irradiated Ebola virus: protection in mice requires CD4(+) T cells. J Virol (2002) 76(18):9176-85. doi:10.1128/JVI.76.18.91769185.2002

55. Ohimain EI. Recent advances in the development of vaccines for Ebola virus disease. Virus Res (2016) 211:174-85. doi:10.1016/j.virusres.2015. 10.021

56. Martin JE, Sullivan NJ, Enama ME, Gordon IJ, Roederer M, Koup RA, et al. A DNA vaccine for Ebola virus is safe and immunogenic in a phase I clinical trial. Clin Vaccine Immunol (2006) 13(11):1267-77. doi:10.1128/ CVI.00162-06

57. Patel A, Scott V, Wong G, Reuschel E, Villarreal D, Muthumani K, et al. A single immunization with optimized DNA vaccines protects against lethal Ebola virus challenge in mice (VAC8P.1057). J Immunol (2015) 194(1 Suppl): 144.13 .

58. Vastag B. Ebola vaccines tested in humans, monkeys. JAMA (2004) 291: 549-50. doi:10.1001/jama.291.5.549

59. Grant-Klein RJ, Altamura LA, Badger CV, Bounds CE, Van Deusen NM, Kwilas SA, et al. Codon-optimized filovirus DNA vaccines delivered by intramuscular electroporation protect cynomolgus macaques from lethal Ebola and Marburg virus challenges. Hum Vaccin Immunother (2015) 11(8):1991-2004. doi:10.1080/21645515.2015.1039757

60. Kibuuka H, Berkowitz NM, Millard M, Enama ME, Tindikahwa A, Sekiziyivu AB, et al. Safety and immunogenicity of Ebola virus and Marburg virus glycoprotein DNA vaccines assessed separately and concomitantly in healthy Ugandan adults: a phase $1 \mathrm{~b}$, randomised, double-blind, placebocontrolled clinical trial. Lancet (2015) 385(9977):1545-54. doi:10.1016/S01406736(14)62385-0

61. Sarwar UN, Costner P, Enama ME, Berkowitz N, Hu Z, Hendel CS, et al. Safety and immunogenicity of DNA vaccines encoding Ebola virus and Marburg virus wild-type glycoproteins in a phase I clinical trial. J Infect Dis (2015) 211(4):549-57. doi:10.1093/infdis/jiu511

62. Warfield KL, Posten NA, Swenson DL, Olinger GG, Esposito D, Gillette WK, et al. Filovirus-like particles produced in insect cells: immunogenicity and protection in rodents. J Infect Dis (2007) 196(Suppl 2):S421-9. doi:10.1086/ 520612

63. Carra JH, Martins KAO, Schokman RD, Robinson CG, Steffens JT, Bavari S. A thermostable, chromatographically purified Ebola nano-VLP vaccine. J Transl Med (2015) 13:228. doi:10.1186/s12967-015-0593-y 
64. Warfield KL, Perkins JG, Swenson DL, Deal EM, Bosio CM, Aman MJ, et al. Role of natural killer cells in innate protection against lethal Ebola virus infection. J Exp Med (2004) 200(2):169-79. doi:10.1084/jem.20032141

65. Rizk MG, Basler CF, Guatelli J. Cooperation of the Ebola virus proteins VP40 and GP1,2 with BST2 to activate NF- $\mathrm{B}$ independently of virus-like particle trapping. J Virol (2017) 91(22):e1308-17. doi:10.1128/JVI.01308-17

66. Cooper CL, Martins KA, Stronsky SM, Langan DP, Steffens J, Van Tongeren S, et al. T-cell-dependent mechanisms promote Ebola VLP-induced antibody responses, but are dispensable for vaccine-mediated protection. Emerg Microbes Infect (2017) 6(6):e46. doi:10.1038/emi.2017.31

67. Reynolds P, Marzi A. Ebola and Marburg virus vaccines. Virus Genes (2017) 53(4):501-15. doi:10.1007/s11262-017-1455-x

68. Herbert AS, Kuehne AI, Barth JF, Ortiz RA, Nichols DK, Zak SE, et al. Venezuelan equine encephalitis virus replicon particle vaccine protects nonhuman primates from intramuscular and aerosol challenge with ebolavirus. J Virol (2013) 87(9):4952-64. doi:10.1128/JVI.03361-12

69. Ren S, Wei Q, Cai L, Yang X, Xing C, Tan F, et al. Alphavirus replicon DNA vectors expressing Ebola GP and VP40 antigens induce humoral and cellular immune responses in mice. Front Microbiol (2018) 8:2662. doi:10.3389/ fmicb.2017.02662

70. Halfmann P, Kim JH, Ebihara H, Noda T, Neumann G, Feldmann H, et al. Generation of biologically contained Ebola viruses. Proc Natl Acad Sci U S A (2008) 105(4):1129-33. doi:10.1073/pnas.0708057105

71. Halfmann P, Ebihara H, Marzi A, Hatta Y, Watanabe S, Suresh M, et al. Replication-deficient ebolavirus as a vaccine candidate. JVirol (2009) 83(8):3810-5. doi:10.1128/JVI.00074-09

72. Marzi A, Halfmann P, Hill-Batorski L, Feldmann F, Shupert WL, Neumann G, et al. An Ebola whole-virus vaccine is protective in nonhuman primates. Science (2015) 348(6233):439-42. doi:10.1126/science.aaa4919

73. Sameem R, Dias S. Ebola virus: promising vaccine candidates. Vaccination Res (2017) 1(1):33-8. doi:10.1080/21645515.2016.1225637

74. Geisbert TW, Feldmann H. Recombinant vesicular stomatitis virus-based vaccines against Ebola and Marburg virus infections. J Infect Dis (2011) 204(Suppl 3):S1075-81. doi:10.1093/infdis/jir349

75. Wong G, Qiu X. Designing efficacious vesicular stomatitis virus-vectored vaccines against Ebola virus. Methods Mol Biol (2016) 1403:245-57. doi:10.1007/978-1-4939-3387-7_12

76. Wit ED, Marzi A, Bushmaker T, Brining D, Scott D, Richt JA, et al. Safety of recombinant VSV-Ebola virus vaccine vector in pigs. Emerg Infect Dis (2015) 21(4):702-4. doi:10.3201/eid2104.142012

77. Halperin SA, Arribas JR, Rupp R, Andrews CP, Chu L, Das R, et al. Sixmonth safety data of recombinant vesicular stomatitis virus-Zaire Ebola virus envelope glycoprotein vaccine in a phase 3 double-blind, placebo-controlled randomized study in healthy adults. J Infect Dis (2017) 215(12):1789-98. doi:10.1093/infdis/jix189

78. Geisbert TW, Daddario-Dicaprio KM, Lewis MG, Geisbert JB, Grolla A, Leung A, et al. Vesicular stomatitis virus-based Ebola vaccine is welltolerated and protects immunocompromised nonhuman primates. PLoS Pathog (2008) 4(11):e1000225. doi:10.1371/journal.ppat.1000225

79. Marzi A, Murphy AA, Feldmann F, Parkins CJ, Haddock E, Hanley PW, et al. Cytomegalovirus-based vaccine expressing Ebola virus glycoprotein protects nonhuman primates from Ebola virus infection. Sci Rep (2016) 6:21674. doi:10.1038/srep21674

80. Venkatraman N, Silman D, Folegatti PM, Hill AVS. Vaccines against Ebola virus. Vaccine (2017). doi:10.1016/j.vaccine.2017.07.054

81. Henao-Restrepo A, Camacho A, Longini IM, Watson CH, Edmunds WJ, Egger M, et al. Efficacy and effectiveness of an rVSV-vectored vaccine in preventing Ebola virus disease: final results from the Guinea ring vaccination, open-label, cluster-randomized trial (Ebola Ca Suffit!). Lancet (2017) 389(10068):505-18. doi:10.1016/S0140-6736(16)32621-6

82. Regules JA, Beigel JH, Paolino KM, Voell J, Castellano AR, Hu Z, et al. A recombinant vesicular stomatitis virus Ebola vaccine. N Engl J Med (2017) 376:330-41. doi:10.1056/NEJMoa1414216

83. Folayan MO, Yakubu A, Haire B, Peterson K. Ebola vaccine development plan: ethics, concerns and proposed measures. BMC Med Ethics (2016) 17:10. doi:10.1186/s12910-016-0094-4

84. Trad MA, Naughton W, Yeung A, Mazlin L, O’sullivan M, Gilroy N, et al. Ebola virus disease: an update on current prevention and management strategies. J Clin Virol (2017) 86:5-13. doi:10.1016/j.jcv.2016.11.005
85. Wang D, Raja NU, Trubey CM, Juompan LY, Luo M, Woraratanadharm J, et al. Development of a cAdVax-based bivalent Ebola virus vaccine that induces immune responses against both the Sudan and Zaire species of Ebola virus. J Virol (2006) 80(6):2738-46. doi:10.1128/JVI.80.6.2738-2746.2006

86. Wang SR, Zhang QY, Wang JQ, Ge XY, Song YY, Wang YF, et al. Chemical targeting of a G-quadruplex RNA in the Ebola virus L gene. Cell Chem Biol (2016) 23(9):1113-22. doi:10.1016/j.chembiol.2016.07.019

87. Dolzhikova IV, Zubkova OV, Tukhvatulin AI, Dzharullaeva AS, Tukhvatulina NM, Shcheblyakov DV, et al. Safety and immunogenicity of GamEvac-Combi, a heterologous VSV- and Ad5-vectored Ebola vaccine: an open phase I/II trial in healthy adults in Russia. Hum Vaccin Immunother (2017) 13(3):613-20. doi:10.1080/21645515.2016.1238535

88. Zhu FC, Hou LH, Li JX, Wu SP, Liu P, Zhang GR, et al. Safety and immunogenicity of a novel recombinant adenovirus type- 5 vector-based Ebola vaccine in healthy adults in China: preliminary report of a randomised, double-blind, placebo-controlled, phase 1 trial. Lancet (2015) 385(9984): 2272-9. doi:10.1016/S0140-6736(15)60553-0

89. Wong G, Mendoza EJ, Plummer FA, Gao GF, Kobinger GP, Qiu X. From bench to almost bedside: the long road to a licensed Ebola virus vaccine. Expert Opin Biol Ther (2018) 18(2):159-73. doi:10.1080/14712598.2018. 1404572

90. Chen T, Li D, Song Y, Yang X, Liu Q, Jin X, et al. A heterologous prime-boost Ebola virus vaccine regimen induces durable neutralizing antibody response and prevents Ebola virus-like particle entry in mice. Antiviral Res (2017) 145:54-9. doi:10.1016/j.antiviral.2017.07.009

91. Ledgerwood JE, DeZure AD, Stanley DA, Coates EE, Novik L, Enama ME, et al. Chimpanzee adenovirus vector Ebola vaccine. N Engl J Med (2017) 376(10):928-38. doi:10.1056/NEJMoa1410863

92. Wong G, Qiu X, Ebihara H, Feldmann H, Kobinger GP. Characterization of a bivalent vaccine capable of inducing protection against both Ebola and cross-clade H5N1 influenza in mice. J Infect Dis (2015) 212(Suppl 2): S435-42. doi:10.1093/infdis/jiv257

93. Ewer K, Rampling T, Venkatraman N, Bowyer G, Wright D, Lambe T, et al. A monovalent chimpanzee adenovirus Ebola vaccine boosted with MVA. New Engl J Med (2016) 374(17):1635-46. doi:10.1056/NEJMoa1411627

94. Milligan ID, Gibani MM, Sewell R, Clutterbuck EA, Campbell D, Plested E, et al. Safety and immunogenicity of novel adenovirus type 26- and modified vaccinia Ankara-vectored Ebola vaccines: a randomized clinical trial. JAMA (2016) 315(15):1610-23. doi:10.1001/jama.2016.4218

95. Schweneker M, Laimbacher AS, Zimmer G, Wagner S, Schraner EM, Wolferstätter $\mathrm{M}$, et al. Recombinant modified vaccinia virus Ankara generating Ebola virus-like particles. J Virol (2017) 91(12). doi:10.1128/JVI. 00343-17

96. Bengtsson KL, Song H, Stertman L, Liu Y, Flyer DC, Massare MJ, etal. Matrix-M adjuvant enhances antibody, cellular and protective immune responses of a Zaire Ebola/Makona virus glycoprotein (GP) nanoparticle vaccine in mice. Vaccine (2016) 34(16):1927-35. doi:10.1016/j.vaccine.2016.02.033

97. Meyer M, Garron T, Lubaki NM, Mire CE, Fenton KA, Klages C, et al. Aerosolized Ebola vaccine protects primates and elicits lung-resident T cell responses. J Clin Invest (2015) 125(8):3241-55. doi:10.1172/JCI81532

98. De Santis O, Audran R, Pothin E, Warpelin-Decrausaz L, Vallotton L, Wuerzner G, et al. Safety and immunogenicity of a chimpanzee adenovirusvectored Ebola vaccine in healthy adults: a randomised, double-blind, placebo controlled, dose-finding, phase 1/2a study. Lancet Infect Dis (2016) 16(3):311-20. doi:10.1016/S1473-3099(15)00486-7

99. Sullivan NJ, Geisbert TW, Geisbert JB, Shedlock DJ, Xu L, Lamoreaux L, et al. Immune protection of nonhuman primates against Ebola virus with single low-dose adenovirus vectors encoding modified GPs. PLoS Med (2006) 3(6):e177. doi:10.1371/journal.pmed.0030177

100. Budzianowski J. Tobacco against Ebola virus disease. Przegl Lek (2015) 72(10):567-71.

101. Phoolcharoen W. Plant-Produced Ebola Immune Complex as an Ebola Vaccine Candidate. Ph.D. thesis. Arizona State University (2010).

102. Monreal-Escalante E, Ramos-Vega AA, Salazar-González JA, BañuelosHernández B, Angulo C, Rosales-Mendoza S. Expression of the VP40 antigen from the Zaire ebolavirus in tobacco plants. Planta (2017) 246(1):123-32. doi:10.1007/s00425-017-2689-5

103. Zeitlin L, Pettitt J, Scully C, Bohorova N, Kim D, Pauly M, et al. Enhanced potency of a fucose-free monoclonal antibody being developed as an Ebola 
virus immunoprotectant. Proc Natl Acad Sci U S A (2011) 108(51):20690-4. doi:10.1073/pnas.1108360108

104. Laere E, Ling APK, Wong YP, Koh RY, Lila MAM, Hussein S. Plant-based vaccines: production and challenges. J Botany (2016) 2016:1-11. doi:10.1155/ 2016/4928637

105. Huang Z, Phoolcharoen W, Lai H, Piensook K, Cardineau G, Zeitlin L, et al. High-level rapid production of full-size monoclonal antibodies in plants by a single-vector DNA replicon system. Biotechnol Bioeng (2010) 106:9-17. doi:10.1002/bit.22652

106. Dhama K, Wani MY, Deb R, Karthik K, Tiwari R, Barathidasan R, et al. Plant based oral vaccines for human and animal pathogens - a new era of prophylaxis: current and future perspectives. J Exp Biol Agric Sci (2013) 1(1): 1-12. doi:10.1177/2051013615613272

107. Kopertekh L, Schiemann J. Transient production of recombinant pharmaceutical proteins in plants: evolution and perspectives. Curr Med Chem (2017). doi:10.2174/0929867324666170718114724

108. Johnson RF, Kurup D, Hagen KR, Fisher C, Keshwara R, Papaneri A, et al. An inactivated rabies virus-based Ebola vaccine, filorab1, adjuvanted with glucopyranosyl lipid A in stable emulsion confers complete protection in nonhuman primate challenge models. JInfect Dis (2016) 214(Suppl 3):S342-54. doi:10.1093/infdis/jiw231

109. Blaney JE, Marzi A, Willet M, Papaneri AB, Wirblich C, Feldmann F, et al. Antibody quality and protection from lethal Ebola virus challenge in nonhuman primates immunized with rabies virus based bivalent vaccine. PLoS Pathog (2013) 9(5):e1003389. doi:10.1371/journal.ppat.1003389

110. Grant-Klein RJ, Van Deusen NM, Badger CV, Hannaman D, Dupuy LC, Schmaljohn CS. A multiagent filovirus DNA vaccine delivered by intramuscular electroporation completely protects mice from Ebola and Marburg virus challenge. Hum Vaccin Immunother (2012) 8(11):1703-6. doi:10.4161/ hv. 21873

111. Shedlock DJ, Aviles J, Talbott KT, Wong G, Wu SJ, Villarreal DO, et al. Induction of broad cytotoxic $\mathrm{T}$ cells by protective DNA vaccination against Marburg and Ebola. Mol Ther (2013) 21(7):1432-44. doi:10.1038/mt. 2013.61

112. Warfield KL, Bosio CM, Welcher BC, Deal EM, Mohamadzadeh M, Schmaljohn A, et al. Ebola virus-like particles protect from lethal Ebola virus infection. Proc Natl Acad Sci U S A (2003) 100(26):15889-94. doi:10.1073/ pnas. 2237038100

113. Swenson DL, Warfield KL, Negley DL, Schmaljohn A, Aman MJ, Bavari S. Virus-like particles exhibit potential as a pan-filovirus vaccine for both Ebola and Marburg viral infections. Vaccine (2005) 23(23):3033-42. doi:10.1016/j. vaccine.2004.11.070

114. Warfield KL, Swenson DL, Olinger GG, Kalina WV, Aman MJ, Bavari S. Ebola virus-like particle-based vaccine protects nonhuman primates against lethal Ebola virus challenge. J Infect Dis (2007) 196(Suppl 2):S430-7. doi:10.1086/520583

115. Domi A, Feldmann F, Basu R, McCurley N, Shifflett K, Emanuel J, et al. A single dose of modified vaccinia Ankara expressing Ebola virus like particles protects nonhuman primates from lethal Ebola virus challenge. Sci Rep (2018) 8:864. doi:10.1038/s41598-017-19041-y

116. Pushko P, Bray M, Ludwig GV, Parker M, Schmaljohn A, Sanchez A, et al. Recombinant RNA replicons derived from attenuated Venezuelan equine encephalitis virus protect guinea pigs and mice from Ebola hemorrhagic fever virus. Vaccine (2000) 19(1):142-53. doi:10.1016/S0264-410X(00)00113-4

117. Tsuda Y, Caposio P, Parkins CJ, Botto S, Messaoudi I, Cicin-Sain L, et al. A replicating cytomegalovirus-based vaccine encoding a single Ebola virus nucleoprotein CTL epitope confers protection against Ebola virus. PLoS Negl Trop Dis (2011) 5(8):e1275. doi:10.1371/journal.pntd.0001275

118. Reynard O, Mokhonov V, Mokhonova E, Leung J, Page A, Mateo M, et al. Kunjin virus replicon-based vaccines expressing Ebola virus glycoprotein GP protect the guinea pig against lethal Ebola virus infection. J Infect Dis (2011) 204(Suppl 3):S1060-5. doi:10.1093/infdis/jir347

119. Bukreyev AA, Dinapoli JM, Yang L, Murphy BR, Collins PL. Mucosal parainfluenza virus-vectored vaccine against Ebola virus replicates in the respiratory tract of vector-immune monkeys and is immunogenic. Virology (2010) 399(2):290-8. doi:10.1016/j.virol.2010.01.015

120. DiNapoli JM, Yang L, Samal SK, Murphy BR, Collins PL, Bukreyev A. Respiratory tract immunization of non-human primates with a Newcastle disease virus-vectored vaccine candidate against Ebola virus elicits a neutralizing antibody response. Vaccine (2010) 29(1):17-25. doi:10.1016/j. vaccine.2010.10.024

121. Ledgerwood JE, Costner P, Desai N, Holman L, Enama ME, Yamshchikov G, et al. A replication defective recombinant Ad5 vaccine expressing Ebola virus GP is safe and immunogenic in healthy adults. Vaccine (2010) 29(2):304-13. doi:10.1016/j.vaccine.2010.10.037

122. Agnandji ST, Huttner A, Zinser ME, Njuguna P, Dahlke C, Fernandes JF, et al. Phase 1 trials of rVSV Ebola vaccine in Africa and Europe. N Engl J Med (2016) 374:1647-60. doi:10.1056/NEJMoa1502924

123. Cardile AP, Downey LG, Wiseman PD, Warren TK, Bavari S. Antiviral therapeutics for the treatment of Ebola virus infection. Curr Opin Pharmacol (2016) 30:138-43. doi:10.1016/j.coph.2016.08.016

124. Bishop BM. Potential and emerging treatment options for Ebola virus disease. Ann Pharmacother (2015) 49(2):196-206. doi:10.1177/1060028014561227

125. Shao X, Ren W, Zhou F. Clinical presentation and care for patients with Ebola virus disease in China Ebola treatment unit, Liberia. Jpn J Infect Dis (2016) 70(1):32-7. doi:10.7883/yoken.JJID.2015.597

126. Madariaga MG. Ebola virus disease: a perspective for the United States. Am J Med (2015) 128(7):682-91. doi:10.1016/j.amjmed.2015.01.035

127. Choi JH, Croyle MA. Emerging targets and novel approaches to Ebola virus prophylaxis and treatment. Bio Drugs (2013) 27(6):565-83. doi:10.1007/ s40259-013-0046-1

128. Kilgore PE, Grabenstein JD, Salim AM, Rybak M. Treatment of Ebola virus disease. Pharmacotherapy (2015) 35:43-53. doi:10.1002/phar.1545

129. Smither SJ, Eastaugh LS, Steward JA, Nelson M, Lenk RP, Lever MS. Postexposure efficacy of oral T-705 (Favipiravir) against inhalational Ebola virus infection in a mouse model. Antiviral Res (2014) 104:153-5. doi:10.1016/j. antiviral.2014.01.012

130. Duraffour S, Malvy D, Sissoko D. How to treat Ebola virus infections? A lesson from the field. Curr Opin Virol (2017) 24:9-15. doi:10.1016/j. coviro.2017.03.003

131. Zhang T, Zhai M, Ji J, Zhang J, Tian Y, Liu X. Recent progress on the treatment of Ebola virus disease with Favipiravir and other related strategies. Bioorg Med Chem Lett (2017) 27(11):2364-8. doi:10.1016/j.bmcl.2017.04.028

132. Cheng F, Murray JL, Zhao J, Sheng J, Zhao Z, Rubin DH. Systems biologybased investigation of cellular antiviral drug targets identified by gene-trap insertional mutagenesis. PLoS Comput Biol (2016) 12:e1005074. doi:10.1371/ journal.pcbi.1005074

133. Ahmad N, Farman A, Badshah SL, Ur Rahman A, Ur Rashid H, Khan K. Molecular modeling, simulation and docking study of Ebola virus glycoprotein. J Mol Graph Model (2016) 72:266-71. doi:10.1016/j.jmgm.2016.12.010

134. Alam El-Din HM, Loutfy SA, Fathy N, Elberry MH, Mayla AM, Kassem S, et al. Molecular docking based screening of compounds against VP40 from Ebola virus. Bioinformation (2016) 12:192-6. doi:10.6026/97320630012192

135. Yates MK, Raje MR, Chatterjee P, Spiropoulou CF, Bavari S, Flint M, et al. Flex-nucleoside analogues - novel therapeutics against filoviruses. Bioorg Med Chem Lett (2017) 27(12):2800-2. doi:10.1016/j.bmcl.2017.04.069

136. Alfson KJ, Worwa G, Carrion R Jr, Griffiths A. Determination and therapeutic exploitation of Ebola virus spontaneous mutation frequency. J Virol (2015) 90(5):2345-55. doi:10.1128/JVI.02701-15

137. Tseng CP, Chan YJ. Overview of Ebola virus disease in 2014. JChin Med Assoc (2015) 78:51-5. doi:10.1016/j.jcma.2014.11.007

138. AllAfrica. (2014). Available from: http://allafrica.com/stories/201409292050. html (Accessed: March, 2018).

139. Cong Y, Dyall J, Hart BJ, DeWald LE, Johnson JC, Postnikova E, et al. Evaluation of the activity of lamivudine and zidovudine against Ebola virus. PLoS One (2016) 11(11):e0166318. doi:10.1371/journal.pone.0166318

140. Hensley LE, Dyall J, Olinger GG, Jahrling PB. Lack of effect of lamivudine on Ebola virus replication. Emerg Infect Dis (2015) 21(3):550-2. doi:10.3201/ eid2103.141862

141. Raj U, Varadwaj PK. Flavonoids as multi-target inhibitors for proteins associated with Ebola virus: in silico discovery using virtual screening and molecular docking studies. Interdiscip Sci (2016) 8(2):142. doi:10.1007/ s12539-015-0125-8

142. Bradfute SB. The early clinical development of Ebola virus treatments. Expert Opin Investig Drugs (2017) 26(1):1-4. doi:10.1080/13543784.2017. 1260545 
143. Pokhrel R, Jeevan GC, Bhattarai N, Chapagain P, Gerstman B. Potential disruption of Ebola virus matrix by graphene nano-sheets. Biophysical J (2018) 114(3):218a. doi:10.1016/j.bpj.2017.11.1217

144. Shtanko O, Sakurai Y, Reyes AN, Noel R, Cintrat JC, Gillet D, et al. Retro-2 and its dihydroquinazolinone derivatives inhibit filovirus infection. Antiviral Res (2018) 149:154-63. doi:10.1016/j.antiviral.2017.11.016

145. Qiu S, Leung A, Bo Y, Kozak RA, Anand SP, Warkentin C, et al. Ebola virus requires phosphatidylinositol $(3,5)$ bisphosphate production for efficient viral entry. Virology (2018) 513:17-28. doi:10.1016/j.virol.2017.09.028

146. Nelson EA, Dyall J, Hoenen T, Barnes AB, Zhou H, Liang JY, et al. The phosphatidylinositol-3-phosphate 5-kinase inhibitor apilimod blocks filoviral entry and infection. PLoS Negl Trop Dis (2017) 11(4):e0005540. doi:10.1371/ journal.pntd.0005540

147. Jerebtsova M, Nekhai S. Therapeutics for postexposure treatment of Ebola virus infection. Future Virol (2015) 10(3):221-32. doi:10.2217/fvl.14.109

148. Biedenkopf N, Lange-Grunweller K, Schulte FW, Weißer A, Müller C, Becker D, et al. The natural compound silvestrol is a potent inhibitor of Ebola virus replication. Antiviral Res (2017) 137:76-81. doi:10.1016/j. antiviral.2016.11.011

149. Yuan S, Zhang ZW, Li ZL. Improvements in treatment of children younger than age 5 years infected with Ebola virus. JPediatr (2017) 185:251-2. doi:10.1016/j.jpeds.2017.02.025

150. Dhanda SK, Chaudhary K, Gupta S, Brahmachari SK, Raghava GP. A webbased resource for designing therapeutics against Ebola virus. Sci Rep (2016) 6:24782. doi:10.1038/srep24782

151. Matsuno K, Kishida N, Usami K, Igarashi M, Yoshida R, Nakayama E, et al. Different potential of C-type lectin-mediated entry between Marburg virus strains. J Virol (2010) 84:5140-7. doi:10.1128/JVI.02021-09

152. Aleksandrowicz P, Marzi A, Biedenkopf N, Beimforde N, Becker S, Hoenen T, et al. Ebola virus enters host cells by macropinocytosis and clathrin-mediated endocytosis. J Infect Dis (2011) 204(Suppl 3):S957-67. doi:10.1093/infdis/ jir326

153. Miller EH, Obernosterer G, Raaben M, Herbert AS, Deffieu MS, Krishnan A, et al. Ebola virus entry requires the host-programmed recognition of an intracellular receptor. EMBO J (2012) 31:1947-60. doi:10.1038/emboj.2012.53

154. Kondratowicz AS, Lennemann NJ, Sinn PL, Davey RA, Hunt CL, MollerTank S, et al. T-cell immunoglobulin and mucin domain 1 (TIM-1) is a receptor for Zaire Ebolavirus and Lake Victoria Marburgvirus. Proc Natl Acad Sci US A (2011) 108(20):8426-31. doi:10.1073/pnas.1019030108

155. Côté M, Misasi J, Ren T, Bruchez A, Lee K, Filone CM. Small molecule inhibitors reveal Niemann-Pick C1 is essential for Ebola virus infection. Nature (2011) 477(7364):344-8. doi:10.1038/nature10380

156. Sakurai Y, Kolokoltsov AA, Chen CC, Tidwell MW, Bauta WE, Klugbauer N, et al. Two-pore channels control Ebola virus host cell entry and are drug targets for disease treatment. Science (2015) 347:995-8. doi:10.1126/science. 1258758

157. Johansen LM, Brannan JM, Delos SE, Shoemaker CJ, Stossel A, Lear C, et al. FDA-approved selective estrogen receptor modulators inhibit Ebola virus infection. Sci Transl Med (2013) 5:190ra79. doi:10.1126/scitranslmed. 3005471

158. Gehring G, Rohrmann K, Atenchong N, Mittler E, Becker S, Dahlmann F, et al. The clinically approved drugs amiodarone, dronedarone and verapamil inhibit filovirus cell entry. J Antimicrob Chemother (2014) 69:2123-31. doi:10.1093/jac/dku091

159. Salata C, Munegato D, Martelli F, Parolin C, Calistri A, Baritussio A, et al. Amiodarone affects Ebola virus binding and entry into target cells. New Microbiol (2018) 41(2):162-4.

160. Illescas BM, Rojo J, Delgado R, Martín N. Multivalent glycosylated nanostructures to inhibit Ebola virus infection. J Am Chem Soc (2017) 139(17):6018-25. doi:10.1021/jacs.7b01683

161. Sun W, He S, Martínez-Romero C, Kouznetsova J, Tawa G, Xu M, et al. Synergistic drug combination effectively blocks Ebola virus infection. Antiviral Res (2016) 137:165-72. doi:10.1016/j.antiviral.2016.11.017

162. Anantpadma M, Kouznetsova J, Wang H, Huang R, Kolokoltsov A, Guha R, et al. Large-scale screening and identification of novel Ebola virus and Mardburg virus entry inhibitors. Antimicrob Agents Chemother (2016) 60(8):4471-81. doi:10.1128/AAC.00543-16

163. Zhang X, Ao Z, Bello A, Ran X, Liu S, Wigle J, et al. Characterization of the inhibitory effect of an extract of Prunella vulgaris on Ebola virus glycoprotein
(GP)-mediated virus entry and infection. Antiviral Res (2016) 127:20-31. doi:10.1016/j.antiviral.2016.01.001

164. Cheng H, Lear-Rooney CM, Johansen L, Varhegyi E, Chen ZW, Olinger GG, et al. Inhibition of Ebola and Marburg virus entry by $\mathrm{G}$ protein-coupled receptor antagonists. J Virol (2015) 89(19):9932-8. doi:10.1128/JVI.01337-15

165. Qiu X, Kroeker A, He S, Kozak R, Audet J, Mbikay M, et al. Prophylactic efficacy of quercetin 3- $\beta$-O-D-glucoside against Ebola virus infection. Antimicrob Agents Chemother (2016) 60(9):5182-8. doi:10.1128/AAC.00307-16

166. Bornholdt ZA, Ndungo E, Fusco ML, Bale S, Flyak AI, Crowe JE Jr, et al. Host-primed Ebola virus GP exposes a hydrophobic NPC1 receptor-binding pocket, revealing a target for broadly neutralizing antibodies. mBio (2016) 7(1):e2154-2115. doi:10.1128/mBio.02154-15

167. Nishimura H, Yamaya M. A synthetic serine protease inhibitor, nafamostat mesilate, is a drug potentially applicable to the treatment of Ebola virus disease. Tohoku J Exp Med (2015) 237(1):45-50. doi:10.1620/tjem.237.45

168. Li H, Yu F, Xia S, Yu Y, Wang Q, Lv M, et al. Chemically modified human serum albumin potently blocks entry of Ebola pseudoviruses and virus like particles. Antimicrob Agents Chemother (2017) 61(4):e2168-2116. doi:10.1128/ AAC.02168-16

169. van Griensven J, De Weiggheleire A, Delamou A, Smith PG, Edwards T, Vandekerckhove P, et al. The use of Ebola convalescent plasma to treat Ebola virus disease in resource constrained set-tings: a perspective from the field. Clin Infect Dis (2015) 62:69-74. doi:10.1093/cid/civ680

170. Garraud O. Use of convalescent plasma in Ebola virus infection. Transfus Apher Sci (2017) 56(1):31-4. doi:10.1016/j.transci.2016.12.014

171. Gulland A. First Ebola treatment is approved by WHO. British Med J (2014) 349:g5539. doi:10.1136/bmj.g5539

172. Geisen C, Kann G, Strecker T, Wolf T, Schüttfort G, van Kraaij M, et al. Pathogen-reduced Ebola virus convalescent plasma: first steps towards standardization of manufacturing and quality control including assessment of Ebola-specific neutralizing antibodies. Vox Sang (2016) 110(4):329-35. doi: $10.1111 /$ vox. 12376

173. Dye JM, Herbert AS, Kuehne AI, Barth JF, Muhammad MA, Zak SE, et al. Postexposure antibody prophylaxis protects nonhuman primates from filovirus disease. Proc Natl Acad Sci U S A (2012) 109:5034-9. doi:10.1073/ pnas. 1200409109

174. Saphire EO. An update on the use of antibodies against the filoviruses. Immunotherapy (2013) 5:1221-33. doi:10.2217/imt.13.124

175. Corti D, Misasi J, Mulangu S, Stanley DA, Kanekiyo M, Wollen S, et al. Protective monotherapy against lethal Ebola virus infection by a potently neutralizing antibody. Science (2016) 351:1339-42. doi:10.1126/science. aad5224

176. Mire CE, Geisbert JB, Agans KN, Thi EP, Lee AC, Fenton KA, et al. Passive immunotherapy: assessment of convalescent serum against Ebola virus Makona infection in nonhuman primates. J Infect Dis (2016) 214(S3): S367-74. doi:10.1093/infdis/jiw333

177. Borisevich IV, Chemikova NK, Markov VI, Krasnianskiy VP, Borisevich SV, Rozhdestvenskiy EV. An experience in the clinical use of specific immunoglobulin from horse blood serum for prophylaxis of Ebola haemorrhagic fever. Vopr Virusol (2017) 62(1):25-9.

178. Holtsberg FW, Shulenin S, Vu H, Howell KA, Patel SJ, Gunn B, et al. Panebolavirus and pan-filovirus mouse monoclonal antibodies: protection against Ebola and Sudan viruses. J Virol (2016) 90(1):266-78. doi:10.1128/ JVI.02171-15

179. Zhang Y, Li D, Jin X, Huang Z. Fighting Ebola with ZMapp: spotlight on plant-made antibody. Sci China Life Sci (2014) 57:987-8. doi:10.1007/s11427014-4746-7

180. Dornemann J, Burzio C, Ronsse A, Sprecher A, De Clerck H, Van Herp M, et al. First newborn baby to receive experimental therapies survives Ebola virus disease. J Infect Dis (2017) 215(2):171-4. doi:10.1093/infdis/jiw493

181. Hayden FG, Friede M, Bausch DG. Experimental therapies for Ebola virus disease: what have we learned? J Infect Dis (2017) 215:167-70. doi:10.1093/ infdis/jiw496

182. Wec AZ, Herbert AS, Murin CD, Nyakatura EK, Abelson DM, Fels JM, et al. Antibodies from a human survivor define sites of vulnerability for broad protection against Ebola viruses. Cell (2017) 169(5):878.e-90.e. doi:10.1016/j. cell.2017.04.037

183. Duehr J, Wohlbold TJ, Oestereich L, Chromikova V, Amanat F, Rajendran M, et al. Novel cross-reactive monoclonal antibodies against Ebolavirus 
glycoproteins show protection in a murine challenge model. J Virol (2017) 91(16). doi:10.1128/JVI.00652-17

184. Howell KA, Qiu X, Brannan JM, Bryan C, Davidson E, Holtsberg FW, et al. Antibody treatment of Ebola and Sudan virus infection via a uniquely exposed epitope within the glycoprotein receptor-binding site. Cell Rep (2016) 15(7):1514-26. doi:10.1016/j.celrep.2016.04.026

185. Maruyama T, Rodriguez LL, Jahrling PB, Sanchez A, Khan AS, Nichol ST, et al. Ebola virus can be effectively neutralized by antibody produced in natural human infection. J Virol (1999) 73(7):6024-30.

186. Parren PWHI, Geisbert TW, Maruyama T, Jahrling PB, Burton DR. Pre- and postexposure prophylaxis of Ebola virus infection in an animal model by passive transfer of a neutralizing human antibody. J Virol (2002) 76(12):6408-12. doi:10.1128/JVI.76.12.6408-6412.2002

187. Lee JE, Fusco ML, Hessell AJ, Oswald WB, Burton DR, Saphire EO. Structure of the Ebola virus glycoprotein bound to an antibody from a human survivor. Nature (2008) 454(7201):177-82. doi:10.1038/nature07082

188. Howell KA, Brannan JM, Bryan C, McNeal A, Davidson E, Turner HL, et al. Cooperativity enables non-neutralizing antibodies to neutralize Ebolavirus. Cell Rep (2017) 19(2):413-24. doi:10.1016/j.celrep.2017.03.049

189. Wec AZ, Nyakatura EK, Herbert AS, Howell KA, Holtsberg FW, Bakken RR, et al. A "Trojan horse" bispecific antibody strategy for broad protection against ebolaviruses. Science (2016) 354:350-4. doi:10.1126/science.aag3267

190. Teimoori S, Seesuay W, Jittavisutthikul S, Chaisri U, Sookrung N, Densumite J, et al. Human transbodies to VP40 inhibit cellular egress of Ebola virus-like particles. Biochem Bioph Res Co (2016) 479:245-52. doi:10.1016/j.bbrc. 2016.09.052

191. Seesuay S, Jittavisutthikul S, Sae-lim N, Sookrung N, Sakolvaree Y, Chaicumpa W. Human transbodies that interfere with the functions of Ebolavirus VP35 protein in genome replication and transcription and innate immune antagonism. Emerg Microbe Infect (2018) 7(1):41. doi:10.1038/ s41426-018-0031-3

192. Kohler H, Paul S. Superantibody activities: new players in innate and adaptive immune response. Immunol Today (1998) 9(5):221-7. doi:10.1016/ S0167-5699(97)01234-6

193. González-González E, Alvarez MM, Márquez-Ipiña AR, Trujillode Santiago G, Rodríguez-Martínez LM, Annabi N, et al. Anti-Ebola therapies based on monoclonal antibodies: current state and challenges ahead. Crit Rev Biotechnol (2017) 37(1):53-68. doi:10.3109/07388551.2015.1114465

194. Flyak AI, Shen X, Murin CD, Turner HL, David JA, Fusco ML, et al. Crossreactive and potent neutralizing antibody responses in human survivors of natural Ebola virus infection. Cell (2016) 164(3):392-405. doi:10.1016/j. cell.2015.12.022

195. Hernandez H, Marceau C, Halliday H, Callison J, Borisevich V, Escaffre O, et al. Development and characterization of broadly cross-reactive monoclonal antibodies against all known Ebolavirus species. J Infect Dis (2015) 212(Suppl 2):S410-3. doi:10.1093/infdis/jiv209

196. Furuyama W, Marzi A, Nanbo A, Haddock E, Maruyama J, Miyamoto H, et al. Discovery of an antibody for pan-ebolavirus therapy. Sci Rep (2016) 6:20514. doi:10.1038/srep20514

197. Bornholdt ZA, Turner HL, Murin CD, Li W, Sok D, Souders CA, et al. Isolation of potent neutralizing antibodies from a survivor of the 2014 Ebola virus outbreak. Science (2016) 351(6277):1078-83. doi:10.1126/science. aad5788

198. Zhang Q, Gui M, Niu X, He S, Wang R, Feng Y, et al. Potent neutralizing monoclonal antibodies against Ebola virus infection. Sci Rep (2016) 6:25856. doi:10.1038/srep25856

199. Nguyen VK, Hernandez-Vargas EA. Windows of opportunity for Ebola virus infection treatment and vaccination. Sci Rep (2017) 7:8975. doi:10.1038/ s41598-017-08884-0

200. van Lieshout LP, Soule G, Sorensen D, Frost KL, He S, Tierney K, et al. Intramuscular adeno-associated virus-mediated expression of monoclonal antibodies provides $100 \%$ protection against Ebola virus infection in mice. J Infect Dis (2018) 217(6):916-25. doi:10.1093/infdis/jix644

201. Ruggiero E, Richter SN. G-quadruplexes and G-quadruplex ligands: targets and tools in antiviral therapy. Nucleic Acids Res (2018) 46(7):3270-83. doi:10.1093/nar/gky187

202. Warren TK, Wells J, Panchal RG, Stuthman KS, Garza NL, Van Tongeren SA, et al. Protection against filovirus diseases by a novel broad-spectrum nucleoside analogue BCX4430. Nature (2014) 508:402-5. doi:10.1038/nature13027
203. Taylor R, Kotian P, Warren T, Panchal R, Bavari S, Julander J, et al. BCX4430 - a broad-spectrum antiviral adenosine nucleoside analog under development for the treatment of Ebola virus disease. J Infect Public Health (2016) 9:220-6. doi:10.1016/j.jiph.2016.04.002

204. Cardile AP, Warren TK, Martins KA, Reisler RB, Bavari S. Will there be a cure for Ebola? Annu Rev Pharmacol Toxicol (2017) 57:329-48. doi:10.1146/ annurev-pharmtox-010716-105055

205. Olsen ME, Filone CM, Rozelle D, Mire CE, Agans KN, Hensley L, et al. Polyamines and hypusination are required for Ebolavirus gene expression and replication. mBio (2016) 7(4):e882-816. doi:10.1128/mBio.00882-16

206. Sweiti H, Ekwunife O, Jaschinski T, Lhachimi SK. Repurposed therapeutic agents targeting the Ebola virus: a systematic review. Curr Therap Res (2017) 84:10-21. doi:10.1016/j.curtheres.2017.01.007

207. Johnson JC, Martinez O, Honko AN, Hensley LE, Olinger GG, Basler CF. Pyridinyl imidazole inhibitors of p38 MAP kinase impair viral dendritic cells. Antiviral Res (2014) 107:102-9. doi:10.1016/j.antiviral.2014.04.014

208. Dunning J, Kennedy SB, Antierens A, Whitehead J, Ciglenecki I, Carson G, et al. Experimental treatment of Ebola virus disease with brincidofovir. PLoS One (2016) 11:e0162199. doi:10.1371/journal.pone.0162199

209. Chiramel AI, Banadyga L, Dougherty JD, Falzarano D, Martellaro C, Brees D, et al. Alisporivir has limited antiviral effects against Ebola virus strains Makona and Mayinga. J Infect Dis (2016) 214(S3):S355-9. doi:10.1093/ infdis/jiw241

210. Yang S, Xu M, Lee EM, Gorshkov K, Shiryaev SA, He S, et al. Emetine inhibits Zika and Ebola virus infections through two molecular mechanisms: inhibiting viral replication and decreasing viral entry. Cell Discov (2018) 4:31. doi:10.1038/s41421-018-0034-1

211. Wang Y, Cui R, Li G, Gao Q, Yuan S, Altmeyer R, et al. Teicoplanin inhibits Ebola pseudovirus infection in cell culture. Antiviral Res (2016) 125:1-7. doi:10.1016/j.antiviral.2015.11.003

212. Yonezawa A, Cavrois M, Greene WC. Studies of Ebola virus glycoproteinmediated entry and fusion by using pseudotyped human immunodeficiency virus type 1 virions: involvement of cytoskeletal proteins and enhancement by tumor necrosis factor alpha. J Virol (2005) 79(2):918-26. doi:10.1128/ JVI.79.2.918-926.2005

213. Kinch MS, Yunus AS, Lear C, Mao H, Chen H, Fesseha Z, et al. FGI-104: a broad-spectrum small molecule inhibitor of viral infection. Am J Transl Res (2009) 1(1):87-98.

214. Ekins S, Freundlich JS, Coffee M. A common feature pharmacophore for FDA-approved drugs inhibiting the Ebola virus. Version 2. F1000Res (2014) 3:277. doi:10.12688/f1000research.5741.2

215. Madrid PB, Panchal RG, Warren TK, Shurtleff AC, Endsley AN, Green CE, et al. Evaluation of Ebola virus inhibitors for drug repurposing. ACS Infect Dis (2015) 1(7):317-26. doi:10.1021/acsinfecdis.5b00030

216. Salata C, Baritussio A, Munegato D, Calistri A, Ha HR, Bigler L, et al. Amiodarone and metabolite MDEA inhibit Ebola virus infection by interfering with the viral entry process. Pathog Dis (2015) 73(5):ftv032. doi:10.1093/ femspd/ftv032

217. Yuan S. Possible FDA-approved drugs to treat Ebola virus infection. Infect Dis Poverty (2015) 4:23. doi:10.1186/s40249-015-0055-z

218. Johansen LM, DeWald LE, Shoemaker CJ, Hoffstrom BG, Lear-Rooney CM, Stossel A, et al. A screen of approved drugs and molecular probes identifies therapeutics with anti-Ebola virus activity. Sci Transl Med (2015) 7(290):290ra89. doi:10.1126/scitranslmed.aaa5597

219. Takada A, Robison C, Goto H, Sanchez A, Murti KG, Whitt MA, et al. A system for functional analysis of Ebola virus glycoprotein. Proc Natl Acad Sci U S A (1997) 94(26):14764-9. doi:10.1073/pnas.94.26.14764

220. Sissoko D, Laouenan C, Folkesson E, M'Lebing AB, Beavogui AH, Baize $\mathrm{S}$, et al. Experimental treatment with favipiravir for Ebola virus disease (the JIKI Trial): a historically controlled, single-arm proof-of-concept trial in Guinea. PLoS Med (2016) 13:e1001967. doi:10.1371/journal. pmed.1001967

221. Oestereich L, Ludtke A, Wurr S, Rieger T, Muñoz-Fontela C, Gunther S. Successful treatment of advanced Ebola virus infection with T-705 (favipiravir) in a small animal model. Antiviral Res (2014) 105:17-21. doi:10.1016/j. antiviral.2014.02.014

222. Smith DR, McCarthy S, Chrovian A, Olinger G, Stossel A, Geisbert TW, et al. Inhibition of heat-shock protein 90 reduces Ebola virus replication. Antiviral Res (2010) 87(2):187-94. doi:10.1016/j.antiviral.2010.04.015 
223. García M, Cooper A, Shi W, Bornmann W, Carrion R, Kalman D, et al. Productive replication of Ebola virus is regulated by the c-Abll tyrosine kinase. Sci Transl Med (2012) 4(123):123ra24. doi:10.1126/scitranslmed.3003500

224. Nelson EA, Barnes AB, Wiehle RD, Fontenot GK, Hoenen T, White JM. Clomiphene and its isomers block Ebola virus particle entry and infection with similar potency: potential therapeutic implications. Viruses (2016) 8(8): E206. doi:10.3390/v8080206

225. Kouznetsova J, Sun W, Martínez-Romero C, Tawa G, Shinn P, Chen CZ, et al. Identification of 53 compounds that block Ebola virus-like particle entry via a repurposing screen of approved drugs. Emerg Microbes Infect (2014) 3:e84. doi:10.1038/emi.2014.88

226. Madrid PB, Chopra S, Manger ID, Gilfillan L, Keepers TR, Shurtleff AC, et al. A systematic screen of FDA-approved drugs for inhibitors of biological threat agents. PLoS One (2013) 8(4):e60579. doi:10.1371/journal.pone.0060579

227. Panchal RG, Reid SP, Tran JP, Bergeron AA, Wells J, Kota KP, et al. Identification of an antioxidant small-molecule with broad-spectrum antiviral activity. Antiviral Res (2012) 93(1):23-9. doi:10.1016/j.antiviral.2011.10.011

228. Geisbert TW, Hensley LE, Jahrling PB, Larsen T, Geisbert JB, Paragas J, et al. Treatment of Ebola virus infection with a recombinant inhibitor of factor VIIa/tissue factor: a study in rhesus monkeys. Lancet (2003) 362:1953-8. doi:10.1016/S0140-6736(03)15012-X

229. Henß L, Beck S, Weidner T, Biedenkopf N, Sliva K, Weber C, et al. Suramin is a potent inhibitor of Chikungunya and Ebola virus cell entry. Virol J (2016) 13:149. doi:10.1186/s12985-016-0607-2

230. Zhao Z, Martin C, Fan R, Bourne PE, Xie L. Drug repurposing to target Ebola virus replication and virulence using structural systems pharmacology. BMC Bioinformatics (2016) 17:90. doi:10.1186/s12859-016-0941-9

231. Chopra G, Kaushik S, Elkin PL, Samudrala R. Combating Ebola with repurposed therapeutics using the CANDO platform. Molecules (2016) 21(12):E1537. doi:10.3390/molecules21121537

232. Haque A, Hober D, Blondiaux J. Addressing therapeutic options for Ebola virus infection in current and future outbreaks. Antimicrob Agents Chemother (2015) 59:5892-902. doi:10.1128/AAC.01105-15

233. Olsen NJ, Schleich MA, Karp DR. Multifaceted effects of hydroxychloroquine in human disease. Semin Arthritis Rheum (2013) 43:264-72. doi:10.1016/j. semarthrit.2013.01.001

234. Dowall SD, Bosworth A, Watson R, Bewley K, Taylor I, Rayner E, et al. Chloroquine inhibited Ebola virus replication in vitro but failed to protect against infection anddisease in the in vivo guinea pig model. JGen Virol (2015) 96(12):3484-92. doi:10.1099/jgv.0.000309

235. Falzarano D, Safronetz D, Prescott J, Marzi A, Feldmann F, Feldmann H. Lack of protection against Ebola virus from chloroquine in mice and hamsters. Emerg Infect Dis (2015) 21(6):1065-7. doi:10.3201/eid2106.150176

236. Long J, Wright E, Molesti E, Temperton N, Barclay W. Antiviral therapies against Ebola and other emerging viral diseases using existing medicines that block virus entry. Version 2. F1000Res (2015) 4:30. doi:10.12688/ f1000research.6085.2

237. Kuehne A, Tiffany A, Lasry E, Janssens M, Besse C, Okonta C, et al. Impact and lessons learned from mass drug administrations of malaria chemoprevention during the Ebola outbreak in Monrovia, Liberia, 2014. PLoS One (2016) 11:e0161311. doi:10.1371/journal.pone.0161311

238. Furuta Y, Takahashi K, Fukuda Y, Kuno M, Kamiyama T, Kozaki K, et al. In vitro and in vivo activities of anti-influenza virus compound T-705. Antimicrob Agents Chemother (2002) 46:977-81. doi:10.1128/AAC.46.4.977981.2002

239. Van Herp M, Declerck H, Decroo T. Favipiravir-a prophylactic treatment for Ebola contacts? Lancet (2015) 385:2350. doi:10.1016/S0140-6736(15) 61095-9

240. Chinello P, Petrosillo N, Pittalis S, Biava G, Ippolito G, Nicastri E, et al. QTc interval prolongation during favipiravir therapy in an Ebolavirus-infected patient. PLoS Negl Trop Dis (2017) 11(12):e0006034. doi:10.1371/journal. pntd.0006034

241. Nagata T, Lefor AK, Hasegawa M, Ishii M. Favipiravir: a new medication for the Ebola virus disease pandemic. Disaster Med Public Health Prep (2015) 9:79-81. doi:10.1017/dmp.2014.151

242. Veljkovic V, Loiseau PM, Figadere B, Glisic S, Veljkovic N, Perovic VR, et al. Virtual screen for repurposing approved and experimental drugs for candidate inhibitors of EBOLA virus infection. F1000Res (2015) 4:34. doi:10.12688/f1000research.6110.1
243. Paessler S, Huang C, Sencanski M, Veljkovic N, Perovic V, Glisic S, et al. Ibuprofen as a template molecule for drug design against Ebola virus. Front Biosci (Landmark Ed) (2018) 23:947-53. doi:10.2741/4627

244. Siegel D, Hui HC, Doerffler E, Clarke MO, Chun K, Zhang L, et al. Discovery and synthesis of a phosphoramidate prodrug of a Pyrollo[2,1f] [triazin-4-amino] Adenine C-nucleoside (GS-5734) for the treatment of Ebola and emerging viruses. J Med Chem (2017) 60(5):1648-61. doi:10.1021/acs. jmedchem.6b01594

245. Warren TK, Jordan R, Lo MK, Ray AS, Mackman RL, Soloveva V, et al. Therapeutic efficacy of the small molecule GS-5734 against Ebola virus in rhesus monkeys. Nature (2016) 531(7594):381-5. doi:10.1038/ nature 17180

246. Konde MK, Baker DP, Traore FA, Sow MS, Camara A, Barry AA, et al. Interferon $\beta$-1a for the treatment of Ebola virus disease: a historically controlled, single-arm proof-of-concept trial. PLoS One (2017) 12(2):e0169255. doi:10.1371/journal.pone.0169255

247. Ekins S, Lingerfelt MA, Comer JE, Freiberg AN, Mirsalis JC, O'Loughlin K, et al. Efficacy of tilorone dihydrochloride against Ebola virus infection. Antimicrob Agents Chemother (2017) 62:e1711-7.doi:10.1128/AAC.01711-17

248. Warren TK, Warfield KL, Wells J, Swenson DL, Donner KS, Van Tongeren SA, et al. Advanced antisense therapies for postexposure protection against lethal filovirus infections. Nat Med (2010) 16:991-4. doi:10.1038/ nm.2202

249. Geisbert TW, Lee AC, Robbins M, Geisbert JB, Honko AN, Sood V, et al. Post exposure protection of non-human primates against a lethal Ebola virus challenge with RNA interference: a proof-of-concept study. Lancet (2010) 375:1896-905. doi:10.1016/S0140-6736(10)60357-1

250. Warren TK, Whitehouse CA, Wells J, Welch L, Heald AE, Charleston JS, et al. A single phosphorodiamidate morpholino oligomer targeting VP24 protects rhesus monkeys against lethal Ebola virus infection. mBio (2015) 6:e2344-2314. doi:10.1128/mBio.02344-14

251. Bixler SL, Duplantier AJ, Bavari S. Discovering drugs for the treatment of Ebola virus. Curr Treat Options Infect Dis (2017) 9(3):299-317. doi:10.1007/ s40506-017-0130-z

252. Dunning J, Sahr F, Rojek A, Gannon F, Carson G, Idriss B, et al. Experimental treatment of Ebola virus disease with TKM-130803: a single-arm phase 2 clinical trial. PLoS Med (2016) 13(4):e1001997. doi:10.1371/journal.pmed. 1001997

253. Thi EP, Mire CE, Lee AC, Geisbert JB, Zhou JZ, Agans KN, et al. Lipid nanoparticle siRNA treatment of Ebola-virus-Makona-infected nonhuman primates. Nature (2015) 521:362-5. doi:10.1038/nature14442

254. Sheng M, Zhong Y, Chen Y, Du J, Ju X, Zhao C, et al. Hsa-miR-1246, hsamiR$320 \mathrm{a}$ and hsa-miR-196b-5p inhibitors can reduce the cytotoxicity of Ebola virus glycoprotein in vitro. Sci China Life Sci (2014) 57:959-72. doi:10.1007/ s11427-014-4742-y

255. Iversen PL, Warren TK, Wells JB, Garza NL, Mourich DV, Welch LS, et al. Discovery and early development of AVI-7537 and AVI-7288 for the treatment of Ebola virus and Marburg virus infections. Viruses (2012) 4:2806-30. doi: $10.3390 / \mathrm{v} 4112806$

256. Basu A, Mills DM, Mitchell D, Ndungo E, Williams JD, Herbert AS, et al. Novel small molecule entry inhibitors of Ebola virus. J Infect Dis (2015) 212(Suppl 2):S425-34. doi:10.1093/infdis/jiv223

257. Mupapa K, Massamba M, Kibadi K, Kuvula K, Bwaka A, Kipasa M, et al. Treatment of Ebola hemorrhagic fever with blood transfusions from convalescent patients. International Scientific and Technical Committee. J Infect Dis (1999) 179(Suppl 1):S18-23. doi:10.1086/514298

258. Dye JM, Wu H, Hooper JW, Khurana S, Kuehne AI, Coyle EM, et al. Production of potent fully human polyclonal antibodies against Ebola Zaire virus in transchromosomal cattle. Sci Rep (2016) 6:24897. doi:10.1038/ srep24897

259. Li D, Chen T, Hu Y, Zhou Y, Liu Q, Zhou D, et al. An Ebola virus-like particlebased reporter system enables evaluation of antiviral drugs in vitro under non-biosafety level 4 conditions. J Virol (2016) 90(19):8720-8. doi:10.1128/ JVI.01239-16

260. Shabman RS, Leung DW, Johnson J, Glennon N, Gulcicek EE, Stone KL, et al. DRBP76 associates with Ebola virus VP35 and suppresses viral polymerase function. J Infect Dis (2011) 204:S911-8. doi:10.1093/infdis/jir343

261. McCarthy SD, Majchrzak-Kita B, Racine T, Kozlowski HN, Baker DP, Hoenen $\mathrm{T}$, et al. A rapid screening assay identifies monotherapy with 
interferon- $\beta$ and combination therapies with nucleoside analogs as effective inhibitors of Ebola virus. PLoS Negl Trop Dis (2016) 10(1):e0004364. doi:10.1371/journal.pntd.0004364

262. Audet J, Wong G, Wang H, Lu G, Gao GF, Kobinger G, et al. Molecular characterization of the monoclonal antibodies composing ZMAb: a protective cocktail against Ebola virus. Sci Rep (2014) 4:6881. doi:10.1038/srep06881

263. Modrof J, Mühlberger E, Klenk HD, Becker S. Phosphorylation of VP30 impairs Ebola virus transcription. J Biol Chem (2002) 277(36):33099-104. doi:10.1074/jbc.M203775200

264. Aman MJ, Kinch MS, Warfield K, Warren T, Yunus A, Enterlein S, et al. Development of a broad-spectrum antiviral with activity against Ebola virus. Antiviral Res (2009) 83(3):245-51. doi:10.1016/j.antiviral.2009.06.001

265. Kolokoltsov AA, Adhikary S, Garver J, Johnson L, Davey RA, Vela EM. Inhibition of Lassa virus and Ebola virus infection in host cells treated with the kinase inhibitors genistein and tyrphostin. Arch Virol (2012) 157(1):121-7. doi:10.1007/s00705-011-1115-8

266. Huggins J, Zhang ZX, Bray M. Antiviral drug therapy of filovirus infections: S-adenosylhomocysteine hydrolase inhibitors inhibit Ebola virus in vitro and in a lethal mouse model. J Infect Dis (1999) 179(Suppl 1):S240-7. doi:10.1086/514316

267. Geisbert TW, Hensley LE, Kagan E, Yu EZ, Geisbert JB, Daddario-DiCaprio K, et al. Postexposure protection of guinea pigs against a lethal Ebola virus challenge is conferred by RNA interference. J Infect Dis (2006) 193(12):1650-7. doi:10.1086/504267

268. Enterlein S, Warfield KL, Swenson DL, Stein DA, Smith JL, Gamble CS, et al. VP35 knockdown inhibits Ebola virus amplification and protects against lethal infection in mice. Antimicrob Agents Chemother (2006) 50(3):984-93. doi:10.1128/AAC.50.3.984-993.2006

269. Golkar Z, Battaria R, Pace DG, Bagasra O. Inhibition of Ebola virus by anti-Ebola miRNAs in silico. J Infect Dev Ctries (2016) 10(6):626-34. doi:10.3855/jidc.7127

270. Rocker AE, Müller JA, Dietzel E, Harms M, Krüger F, Heid C, et al. The molecular tweezer CLR01 inhibits Ebola and Zika virus infection. Antiviral Res (2018) 152:26-35. doi:10.1016/j.antiviral.2018.02.003

271. Balmith M, Faya M, Soliman ME. Ebola virus: a gap in drug design and discovery - experimental and computational perspective. Chem Biol Drug Des (2017) 89(3):297-308. doi:10.1111/cbdd.12870

272. Balmith M, Soliman MES. Potential Ebola drug targets - filling the gap: a critical step forward towards the design and discovery of potential drugs. Biologia (2017) 72(1):1-13. doi:10.1515/biolog-2017-0012

273. Schuler J, Hudson ML, Schwartz D, Samudrala R. A systematic review of computational drug discovery, development, and repurposing for Ebola virus disease treatment. Molecules (2017) 22(1777):1-27. doi:10.3390/molecules22101777
274. Dhama K, Chakraborty S, Mahima, Wani MY, Verma AK, Deb R, et al. Novel and emerging therapies safeguarding health of humans and their companion animals: a review. Pak J Biol Sci (2013) 16:101-11. doi:10.3923/ pjbs.2013.101.111

275. Dhama K, Karthik K, Khandia R, Munjal A, Tiwari R, Rana R, et al. Medicinal and therapeutic potential of herbs and plant metabolites/extracts countering viral pathogens - current knowledge and future prospects. Curr Drug Metab (2018). doi:10.2174/1389200219666180129145252

276. Malik YS, Sharma K, Jeena LM, Kumar N, Sircar S, Rajak KK, et al. Toll-like receptors: the innate immune receptors with ingenious anti-viral paradigm. South Asian J Exp Biol (2013) 3:207-13.

277. Gao J, Yin L. Drug development for controlling Ebola epidemic - a race against time. Drug Discov Ther (2014) 8:229-31. doi:10.5582/ ddt.2014.01040

278. Arntzen C. Plant-made pharmaceuticals: from "Edible Vaccines" to Ebola therapeutics. Plant Biotechnol (2015) 13:1013-6. doi:10.1111/pbi.12460

279. Streatfield SJ, Kushnir N, Yusibov V. Plant-produced candidate countermeasures against emerging and re-emerging infections and bioterror agents. Plant Biotechnol J (2015) 13:1136-59. doi:10.1111/pbi.12475

280. Yao J, Weng Y, Dickey A, Wang KY. Plants as factories for human pharmaceuticals: applications and challenges. Int J Mol Sci (2015) 16:28549-65. doi:10.3390/ijms161226122

281. Iqbal HM, Villalba A, Khandia R, Munjal A, Dhama K. Recent trends in nanotechnology-based drugs and formulations for targeted therapeutic delivery. Recent Pat Inflamm Allergy Drug Discov (2016) 10(2):86-93. doi:10.2174/1872213X10666161213162823

282. Prasad M, Lambe UP, Brar B, Shah I, Manimegalai J, Ranjan K, et al. Nanotherapeutics: an insight into healthcare and multi-dimensional applications in medical sector of the modern world. Biomed Pharmacother (2018) 97:1521-37. doi:10.1016/j.biopha.2017.11.026

Conflict of Interest Statement: All authors declare that there exist no commercial or financial relationships that could in any way lead to a potential conflict of interest.

Copyright $\odot 2018$ Dhama, Karthik, Khandia, Chakraborty, Munjal, Latheef, Kumar, Ramakrishnan, Malik, Singh, Malik, Singh and Chaicumpa. This is an open-access article distributed under the terms of the Creative Commons Attribution License (CC BY). The use, distribution or reproduction in other forums is permitted, provided the original author(s) and the copyright owner(s) are credited and that the original publication in this journal is cited, in accordance with accepted academic practice. No use, distribution or reproduction is permitted which does not comply with these terms. 